Article

\title{
Physicochemical and Enzymatic Soil Properties Influenced by Cropping of Primary Wheat under Organic and Conventional Farming Systems
}

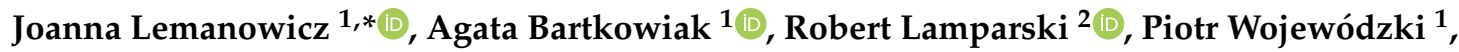 \\ Jarosław Pobereżny $^{3}$ (D), Elżbieta Wszelaczyńska ${ }^{3}$ and Małgorzata Szczepanek ${ }^{4}$ (D) \\ 1 Department of Biogeochemistry and Soil Science, UTP University of Science and Technology in Bydgoszcz, \\ 6/8 Bernardyńska Street, 85-029 Bydgoszcz, Poland; bartkowiak@utp.edu.pl (A.B.); \\ piotr.wojewodzki@utp.edu.pl (P.W.) \\ 2 Department of Biology and Plant Protection, UTP University of Science and Technology, 7 Kaliskiego St., \\ 85-796 Bydgoszcz, Poland; robert@utp.edu.pl \\ 3 Institute of Microbiology and Food Technology, University of Science and Technology, 7 Kaliskiego St., \\ 85-796 Bydgoszcz, Poland; poberezny@utp.edu.pl (J.P.); wszela@utp.edu.pl (E.W.) \\ 4 Department of Agronomy, UTP University of Science and Technology, 7 Kaliskiego St., \\ 85-796 Bydgoszcz, Poland; malgorzata.szczepanek@utp.edu.pl \\ * Correspondence: j109@interia.pl; Tel.: + 48-52-3749-556
}

Received: 7 October 2020; Accepted: 22 October 2020; Published: 26 October 2020

\begin{abstract}
The aim of the study was to assess the content of total organic carbon (TOC), macronutrients $(\mathrm{P}, \mathrm{K}$, and $\mathrm{Mg}$ ), and glomalin (easily extractable glomalin-related soil protein (EEGRSP)) in soil, micronutrients $(\mathrm{Zn}$ and $\mathrm{Cu}$ ) in soil and wheat, and the number of insects on plots in an organic (OF) and a conventional farming (CF) system, all against the background of alkaline phosphatase (AlP) and acid phosphatase (AcP) activity. The experimental design included two spring wheat species, Triticum sphaerococcum Percival and Triticum persicum Vavilov, and three sowing densities (grains $\mathrm{m}^{-2}$ ): $400,500,600$. Statistical analysis (ANOVA, $\eta^{2}$ effect size) showed significant variation in parameters under the influence of experimental factors. In the duration of the field experiment, TOC content in soil had decreased by $61 \%$ compared to the content before starting the experiment. The contents of $\mathrm{P}$, $\mathrm{K}$, and $\mathrm{Mg}$ and activity of AlP and AcP were higher in soil under T. sphaerococcum. With a sowing density of 600 grains $\mathrm{m}^{-2}$ under $\mathrm{OF}$ and $\mathrm{CF}$, the significantly lowest macronutrient content and the highest AlP and AcP activity were found. The parameters tested (TOC, EEGRSP, P, K, Mg, TZn, TCu, $\mathrm{AZn}, \mathrm{CU}$ in plant, AlP, AcP) were higher under the CF than under the OF system. The experimental factors (spring wheat species and number of germinating grains) were demonstrated to influence the content of the forms of both microelements in soil and plants. In CF, more content in the amount of $\mathrm{Zn}$ and $\mathrm{Cu}$ was found than in OF. But the content they had did not exceed the standards set for arable soils. Both wheat species had a significant impact on the concentration of glomalin in the soil from the fields cultivated in the $\mathrm{OF}$ system. In $\mathrm{CF}$, a significant difference was caused by sowing density and by interaction between wheat species and sowing density. Insects preferred plants grown in the OF system compared to CF. Regardless of cultivation system, the number of insects was greater on the plots of T. sphaerococcum than on plots of T. persicum. There were more insects at higher sowing densities in plants grown in the OF system only.
\end{abstract}

Keywords: wheat; macro- and microelements; soil; alkaline and acid phosphatase; glomalin; insects 


\section{Introduction}

Common wheat is mainly grown in the conventional system. Wheat grown in an organic farming system is of much less economic importance. Increased consumer demand has significantly increased organic production of wheat as compared to conventional production [1]. Organic wheat production standards prohibit the use of synthetic chemical crop protection products and certain mineral fertilizers $(\mathrm{N}, \mathrm{KCl}$, and superphosphate) to reduce negative environmental impacts and the risk of pesticide residues being present in grain [2]. Instead, they prescribe inputs of organic fertilizers, and application of preventative and non-chemical crop protection methods. Organic standards also permit the use of some plant or microbial preparations [3,4]. As a result, organic and conventional cropping system of wheat may differ significantly in fertilization and crop protection protocols, as well as in the type of crop varieties used [4-6].

Contemporary conventional agriculture is highly productive and efficient, which affects the soil environment [7]. All cultivation treatments must aim to maintain and increase soil fertility [8]. Over the past decades, farming practice has been taking a growing interest in the organic production system [9,10]. In the new European Council Regulation 2018/848 [11], organic production, is the type of farming that aims to combine best environmental and climate action practices, that prevent or minimize any contribution to the contamination of the environment. Its basic goal is to implement sustainable development principles, an important part of which is the rational management of soil nutrients. Organic carbon (OC) has expanded significantly in Europe and around the world. As a result, it is seen as a sustainable alternative to intensive farming systems [12]. Concerning soil management and fertilization, cultivation practices allowed in organic farming should be specified and conditions should be laid down for the use of fertilizers and conditioners [11]. At the same time, it must maintain a level of soil fertility sufficient for the economic production of plants in the long term, while also protecting the environment. However, organic cereal production is limited by yields being lowered as a result of nutrient deficiencies in the soil, competition from weeds, and greater numbers of insect pests [13]. Poutala et al. [14] hypothesized that older wheat varieties may be better suited to lower soil nutrient levels and greater weed infestation, and less susceptible to insect damage. It should be emphasized that a lot of research has been devoted to such plants as wheat or maize, leading to the development of higher yield varieties that are best suited to the conditions of organic cultivation systems [15].

Conventional agriculture (e.g., high level of mechanization, the use of acidic fertilizers, pesticides) can contribute to environmental degradation (e.g., a loss of biodiversity, soil erosion and acidification, nitrate emissions in soil, deterioration of the soil structure, increasing the content of heavy metals in soil and in food), which has serious consequences for human, animal and plant life [15,16]. One of the important factors influencing the size and quality of crops is the abundance of nutrients available to plants in soils. Assessing soil nutrients' contents allows it to be determined which method of soil use can limit the passage of these elements into the food chain. Soil fertility is assessed mainly on the content of easily absorbable macro- and micronutrients (phosphorus, potassium, magnesium, zinc and copper), taking into account soil pH [17]. Soil factors have the strongest impact on the content of phytoavailable forms of elements in soil, and thus on the level of their accumulation in plants. The amount of microelements taken up by plants depends on their type, content in the soil and forms of occurrence, and on plant species [18].

Metals influence the growth and development of animal organisms [19]. Copper and zinc are microelements of great importance in biological processes and metabolism, where they are important enzymatic agents (associated with around 300 enzymes), but they can be toxic in high concentrations. Thus, excess zinc can seriously disturb the cellular environment, increasing oxidative stress [20,21]. Copper accumulates at the highest concentrations in flowers and is highly mobile in the plant [22]. Polyphagic herbivores can only overcome the toxic effects of metals by avoiding certain foods [23].

Soil extracellular enzymes are a good indicator of soil changes caused by natural (e.g., temperature, rainfall) and anthropogenic (e.g., industry, agriculture, urbanization) factors. They are actively involved in: the decomposition of organic matter released into the soil during plant growth and development and 
the release and availability of mineral substances to plants [24]. Therefore, they can provide immediate and accurate information on the direction of changes in soil quality. Glomalin is described as a soil particle binding agent that is insoluble, heat resistant and hydrophobic [25]. It is also characterized by high Fe content [26]. Glomalin is an organic glycoprotein produced by arbuscular mycorrhizal fungi in the phylum Glomeromycota [27] that colonizes the roots of the majority of vascular plants [28]. Because of its long turnover time, glomalin is an important factor in soil carbon sequestration [29]. The presence of glomalin is higher in grasslands, forest and fallow land than in agricultural soil [8]. It was found that intensive, frequent agrotechnical treatments mixing soil, as well as soil salinization, both result in decreased glomalin concentrations in soil [30,31].

Agriculture development should be established on scientific bases [32], but studies conducted so far do not fully explain the changes in the physical, chemical and enzymatic properties of arable soils, the accumulation of micronutrients in the plant and their impact on changes in the number of insects, especially in the conditions of growing primary forms of wheat, both in conventional, as well as in organic, farming systems. Understanding such phenomena gives an opportunity to improve agricultural practices, increasing biodiversity and sustainable development of conventional and ecological farms.

Therefore, the research objective was to determine the effect that cultivating Indian dwarf wheat and Persian wheat at different sowing densities had on the physicochemical properties, glomalin content, activity of soil phosphatases, and total insect numbers in two cultivation systems: organic and conventional farming ( $\mathrm{OF}$ and $\mathrm{CF}$, respectively).

\section{Materials and Methods}

\subsection{Experiment Design}

Field experiments were located in two localities: Grabina Wielka $\left(52^{\circ} 11^{\prime} \mathrm{N} ; 18^{\circ} 80^{\prime} \mathrm{E}\right)$ - organic farming and Mochełek ( $53^{\circ} 13^{\prime} \mathrm{N} ; 17^{\circ} 51^{\prime}$ E) — conventional farming, in Poland.

In a strict field experiment, three different sowing densities of two species of spring wheat grown using organic and conventional methods were compared. Field research and soil, plant and entomological sampling were conducted in the project years 2018-2020. The test samples were collected in each year of testing in the BBCH 61 phase of spring wheat (in agronomy, the BBCH-scale for cereals describes the phenological development of cereals. $\mathrm{BBCH} 61$-beginning of flowering). The paper presents average research results for the years 2018-2020. The average results from three years of research were aimed at exclude the influence of such factors as temperature and rainfall on the tested parameters.

The whole-plots consisted of wheat species (144 or $254 \mathrm{~m}^{2}$, in conventional and organic cropping system, respectively) and subplots consisted of sowing densities (12.0 and $21.2 \mathrm{~m}^{2}$, respectively).

The factors in the experiment were: factor I-spring wheat species [two levels of factor I: Indian dwarf wheat (Triticum sphaerococcum Percival) and Persian wheat (Triticum persicum Vavilov)]; factor II-number of germinating grains per $\mathrm{m}^{2}$ (three levels of factor II: 400, 500, 600. The experiment was set up in a split-plot arrangement, in four replicates.

Plots with organic farming $(\mathrm{OF})$ and conventional farming $(\mathrm{CF})$ were subject to different agricultural technology methodologies.

\section{Organic Farming}

The forecrops for the tested species of spring wheat grown organic were cereals (triticale or winter wheat). The farms where organic cultivation took place are certified organic by an accredited body. Before starting the experiment, the soil had a medium content of available phosphorus $\left(64.52 \mathrm{mg} \mathrm{kg}^{-1}\right)$, a high content of potassium (182.6 mg kg${ }^{-1}$ ) (both determined with the Egner-Riehm method), and a low content of magnesium (34.37 $\mathrm{mg} \mathrm{kg}^{-1}$ ) (determined with the Schatschabel method), and was slightly acidic (pH 5.9 in $1 \mathrm{M} \mathrm{KCl}$ ) [33]. The content of soil in available P [34], $\mathrm{K}$ [35], and $\mathrm{Mg}$ [36] was 
determined according to the standards. The total organic carbon content was $21.19 \mathrm{~g} \mathrm{~kg}^{-1}$. Immediately after harvesting the forecrop, an intercrop of peas of the tendril-leaved variety 'Tarchalska' were sown in the amount of $240 \mathrm{~kg} \mathrm{ha}^{-1}$. The organic fertilizer Bioilsa $\left(6 \% \mathrm{~N} ; 5 \% \mathrm{P}_{2} \mathrm{O}_{5} ; 13 \% \mathrm{~K}_{2} \mathrm{O} ; 2 \% \mathrm{MgO}\right.$, $10 \% \mathrm{SO}_{3}$ ) was applied by sieving at a dose of $200 \mathrm{~kg}^{-1}$. Pre-winter ploughing was carried out to a depth of $22-23 \mathrm{~cm}$. In the spring, before sowing, the soil was leveled with a cultivating aggregate. Wheat was sown at the end of March using a disc seeder. The amounts sown for achieving densities of 400, 500, and 600 grains $\mathrm{m}^{-2}$ were 148, 185, and $222 \mathrm{~kg} \mathrm{~m}^{-2}$ for Indian dwarf wheat, and 160, 200, and $240 \mathrm{~kg} \mathrm{ha}^{-1}$ for Persian wheat. The amounts to be sown were determined based on the current parameters of the seed material (thousand seed weight and germination capacity) and a field germination rate of $85 \%$. Rolling was performed immediately after sowing. Weed harrowing was performed at the initial wheat tillering stage. Harvesting was performed using a Wintersteiger harvester in late July to mid-August.

\section{Conventional Farming}

Winter triticale was the forecrop for the studied species of conventionally grown spring wheat. Before starting the experiment, the soil had a very high content of available phosphorus (92.43 $\mathrm{mg} \mathrm{kg}^{-1}$ ) [34], a medium content of potassium (156.04 $\mathrm{mg} \mathrm{kg}^{-1}$ ) [35], and a very low content of magnesium (18.69 $\left.\mathrm{mg} \mathrm{kg}^{-1}\right)$ [36], as well as was slightly acidic ( $\mathrm{pH}$ in $1 \mathrm{M} \mathrm{KCl} \mathrm{6.4)} \mathrm{[33].} \mathrm{The} \mathrm{total}$ organic carbon content was $24.31 \mathrm{~g} \mathrm{~kg}^{-1}$. Pre-winter ploughing was carried out to a depth of $22-23 \mathrm{~cm}$. In spring, in the first days of April, pre-sowing fertilization was performed in the amount of: $\mathrm{P}_{2} \mathrm{O}_{5}$ $30 \mathrm{~kg} \mathrm{ha}^{-1}, \mathrm{~K}_{2} \mathrm{O} 50 \mathrm{~kg} \mathrm{ha}^{-1}$, and $\mathrm{N} 30 \mathrm{~kg} \mathrm{ha}^{-1}$. Then, the spring soil was leveled with a cultivating aggregate consisting of a cultivator and a flat-bar roller. The tested spring wheat species was sown in the first ten days of April using a disc seeder with a 12-cm row spacing. The amounts sown for achieving densities of 400, 500, and 600 grains per $\mathrm{m}^{2}$ were 149, 186, and $223 \mathrm{~kg} \mathrm{ha}^{-1}$ for Indian dwarf wheat, and 173, 216, and $260 \mathrm{~kg} \mathrm{ha}^{-1}$ for Persian wheat. The amounts to be sown were determined based on the current parameters of the seed material (thousand seed weight and germination capacity) and a field germination rate of $90 \%$. At all sites, nitrogen was additionally applied at a dose of $30 \mathrm{~kg} \mathrm{ha}^{-1}$ at the end of tillering/the beginning of stem shooting (mid-May). For the conventionally cultivated spring wheat, the following treatments were performed: herbicidal: with Mustang Forte at a dose of $1 \mathrm{~L} \mathrm{ha}^{-1}$ (1st half of May) and after a week Fenoxinn $0.7 \mathrm{~L} \mathrm{ha}^{-1}$; fungicidal: Tango Star $1 \mathrm{~L} \mathrm{ha}^{-1}$ (mid-May), retardant: CCC $7201 \mathrm{~L} \mathrm{ha}^{-1}+$ Cobra $0.5 \mathrm{~L} \mathrm{ha}^{-1}$ (mid-May) and insecticidal: Insodex 0.6 $\mathrm{L} \mathrm{ha}^{-1}+$ Delcaps $100 \mathrm{~mL} \mathrm{ha}^{-1}$ (end of May).

\subsection{Physicochemical Properties}

In air-dried soil samples sieved through a ø 2-mm mesh, the selected physicochemical properties were determined: granulometric composition by laser diffraction method using a Masterssizer MS 2000 (Merven Instrumenyt, Mervern, UK) analyzer, $\mathrm{pH}$ in a $1 \mathrm{M} \mathrm{KCl}$ extract and $\mathrm{H}_{2} \mathrm{O}$ at a ratio of 1:2.5 measured potentiometrically [31], and total organic carbon (TOC) was determined with a Vario Max CNS analyzer (Elementar, Langenselbold, Germany). The content of available forms of phosphorus (P) [34] and potassium (K) were also defined with the Egner-Riehm method (DL) [35], and the content of magnesium available to plants $(\mathrm{Mg})$ following the Schachtschabel method [36]. The total content of zinc $(\mathrm{ZnT})$ and copper $(\mathrm{CuT})$ in soil were determined after mineralization in a mixture of $\mathrm{HF}+\mathrm{HClO}_{4}$ acids according to the method of Crock and Severson [37]. Available forms of zinc $(\mathrm{ZnA})$ and copper $(\mathrm{CuA})$ were extracted with $1 \mathrm{M} \mathrm{HCl}$ by Rinkins' method. $\mathrm{Zn}$ and $\mathrm{Cu}$ in plants were evaluated following mineralization with the microwave technique in concentrated $\mathrm{HNO}_{3}$. The content of macro- and microelements in the extracts obtained by the aforementioned procedures was determined by atomic absorption spectroscopy and atomic emission spectroscopy with the use of a PU 9100X spectrometer (Philips, Cambrigde, UK). The limit of determination for all analyzed metals was $0.2 \mathrm{mg} \mathrm{kg}^{-1}$. To verify the accuracy of the results, analysis of the certified material Loam Soil No. ERM-CC141 and the so-called zero tests were performed, which were exposed to the identical analytic procedure as the soil samples. 
The results facilitated a calculation of the availability factor $(A F \%)$ as suggested by Obrador et al. [38]. It is expressed as follows:

$$
A F=\left(\frac{\text { Available content }}{\text { Total content }}\right) \times 100 .
$$

On the basis of extraction methods, pure glycoprotein is described as "glomalin", whereas pressure extraction of soil in sodium citrate solution results in obtaining the glycoprotein described as "glomalin-related soil protein" (GRSP). Furthermore, the number of extraction cycles specifies easily extractable glomalin-related soil protein (EEGRSP-single extraction cycle) and total extractable glomalin-related soil protein (TGRSP-several extraction cycles). The extraction of EEGRSP was realized according to the protocol evaluated by Wright and Upadhyaya [39]. One gram of soil sample was placed in a 50-mL PP centrifuge tube, then $8 \mathrm{~mL}$ of $20 \mathrm{mM}$ sodium citrate (pH 7.0) was added. The tubes were autoclaved $\left(t=121^{\circ} \mathrm{C}, p=1.4 \mathrm{~kg} \mathrm{~cm}^{-1}, 30 \mathrm{~min}\right)$ and centrifuged $(5000 \times g, 15 \mathrm{~min})$. The collected supernatant was stored at $4{ }^{\circ} \mathrm{C}$ for further analysis. EEGRSP content was determined by the Bradford assay. The extracts were carried into disposable $50-\mu \mathrm{L}$ cuvettes, and the absorbance was measured at $595 \mathrm{~nm}$ by UV-VIS Bio-Rad Smartspec spectrophotometer. The calibration curve was prepared on the basis of ready solutions of bovine serum albumin (BSA). When necessary, extracts were diluted by phosphate buffer saline (PBS) pH 7.4.

\subsection{Enzyme Analysis}

Enzyme activity studies were performed on fresh soils that had been stored at $4{ }^{\circ} \mathrm{C}$ for no more than two weeks. The activity of selected hydrolase enzymes: the soil alkaline phosphatase (AlP) and acid phosphatase (AcP) activities were measured based on the detection of p-nitrophenol (pNP) released after incubation $\left(37^{\circ} \mathrm{C}, 1 \mathrm{~h}\right)$ at $\mathrm{pH} 6.5$ for acid phosphatase and $\mathrm{pH} 11.0$ for alkaline with p-nitrophenyl phosphate disodium [40].

\subsection{Insects Experiments}

The entomological part of the research consisted in collecting insectsby scooping [41,42]. Sampling was performed in the plant development phase that is important for the occurrence of insects-the beginning of spring wheat flowering (BBCH 61). The results of this assessment were presented as the insect density, i.e., total catches by scooping, in individuals per 12 strikes with an entomological net ( 1 strike $=2 \mathrm{~m}^{2}$ of experimental plots).

\subsection{Statistical Analyses}

All experiment results were statistically analyzed using the Statistica 13.1 program. Measurement data $(n=24)$ were analyzed by two-way ANOVA for spring wheat species (I factor), and sowing density (II factor) was calculated independently for OF and for CF. The analysis of variance determined the $\eta^{2}$ effect size, which indicates the percentage share of qualitative variables (spring wheat species and sowing density) in shaping the examined soil and plant parameters and insect numbers. Results are expressed as arithmetic mean plus or minus standard deviation $( \pm \mathrm{SD})$. The relations between the studied parameters were estimated using correlation analysis based on Pearson's correlation coefficients with the level of significance set at $p<0.1, p<0.05 ; p<0.01$. The power of the correlation between soil properties is expressed by the determination coefficient $\left(R^{2}\right)$ and using a regression equation. The correlation coefficient assessed the strength of the relationship between the tested parameters. The coefficient of determination assessed how strong the linear relationship is between these parameters.

In addition, the studied parameters were evaluated using principal component analysis ( $P C A)$. $P C A$ is a variable reduction method which can be used to identify groups of observed variables that tend to cluster together. The results of this analysis are presented as graphics that display traits in 
the arrangement of the first two principal components (PC1 and PC2), which synthetically represent mutually correlated variables.

\section{Results and Discussion}

\subsection{Granulometric Composition and Soil $p H$}

Analysis of the granulometric composition revealed that the soil samples had a similar grain-size distribution. In both the organic and the intensive farm, the sand fraction was highest and the clay fraction lowest (Table 1). Based on the USDA [43] classification, all tested soil samples were classified into one grain-size group: sandy loam. In terms of agrotechnical heaviness, they were classified as medium soils [44]. The tested soils had a $\mathrm{pH}$ in $0.1 \mathrm{M} \mathrm{KCl}$ of 4.50-5.69 in OF (acidic and slightly acidic soil) and 7.36-7.60 in CF (alkaline soil) (Table 1). Wheat is an acid-sensitive crop, and its optimal pH in $\mathrm{KCl}$ range is 6.1-6.5.

Table 1. Granulometric composition and $\mathrm{pH}$ soil in $1 \mathrm{M} \mathrm{KCl}$.

\begin{tabular}{|c|c|c|c|c|c|c|c|c|c|c|c|c|}
\hline \multirow{5}{*}{$\begin{array}{l}\text { Sowing } \\
\text { Density } \\
\text { (II) }\end{array}$} & \multicolumn{6}{|c|}{ Organic Farming (OF) } & \multicolumn{6}{|c|}{ Conventional Farming (CF) } \\
\hline & \multicolumn{12}{|c|}{ Species (I) } \\
\hline & \multicolumn{3}{|c|}{ T. sphaerococcum } & \multicolumn{3}{|c|}{ T. persicum } & \multicolumn{3}{|c|}{ T. sphaerococcum } & \multicolumn{3}{|c|}{ T. persicum } \\
\hline & \multicolumn{12}{|c|}{ Granulometric Composition (\%) } \\
\hline & Sand & Silt & Clay & Sand & Silt & Clay & Sand & Silt & Clay & Sand & Silt & Clay \\
\hline 400 & 67.90 & 29.15 & 3.77 & 66.61 & 29.11 & 4.28 & 54.69 & 40.46 & 4.85 & 55.82 & 39.48 & 4.70 \\
\hline 500 & 63.45 & 32.24 & 4.31 & 63.25 & 32.16 & 4.59 & 51.70 & 43.19 & 5.10 & 54.37 & 40.91 & 4.72 \\
\hline \multirow[t]{2}{*}{600} & 63.39 & 32.18 & 4.43 & 62.74 & 37.72 & 4.53 & 49.21 & 45.31 & 5.58 & 53.87 & 41.38 & 4.75 \\
\hline & \multicolumn{12}{|c|}{$\mathrm{pH} \mathrm{KCl}$} \\
\hline 400 & \multicolumn{3}{|c|}{5.36} & \multicolumn{3}{|c|}{4.50} & \multicolumn{3}{|c|}{7.58} & \multicolumn{3}{|c|}{7.36} \\
\hline 500 & \multicolumn{3}{|c|}{5.08} & \multicolumn{3}{|c|}{5.09} & \multicolumn{3}{|c|}{7.60} & \multicolumn{3}{|c|}{7.48} \\
\hline 600 & \multicolumn{3}{|c|}{5.21} & \multicolumn{3}{|c|}{5.69} & \multicolumn{3}{|c|}{7.52} & \multicolumn{3}{|c|}{7.56} \\
\hline
\end{tabular}

\subsection{Content of TOC, Glomalin, and Available P, K, and $\mathrm{Mg}$ in Soil}

The content of total organic carbon ranged from $7.32( \pm 0.065)$ to $9.53( \pm 0.036)\left(\mathrm{g} \mathrm{kg}^{-1}\right)(\mathrm{mean}$ $\left.8.33 \mathrm{~g} \mathrm{~kg}^{-1}, \pm 0.566\right)(\mathrm{OF})$. In contrast, in CF, the TOC content was higher (from 9.14, \pm 0.032 to $11.56 \mathrm{~g} \mathrm{~kg}^{-1}$, \pm 0.039 ; mean $10.35 \mathrm{~g} \mathrm{~kg}^{-1}, \pm 0.442$ ) (Table 2). Based on the European Soil Database [45,46] classes of TOC content in soils, the studied soils are classified as being of very low TOC content. The TOC content was found to have fallen by $61 \%$ since the start of the experiment. A decrease in TOC content in soils adversely affects their fertility, and this may translate into the size and quality of plant crops [46]. Even a small loss of soil organic matter can degrade soil structure. The appropriate level of organic matter is also important due to the role of soil in sequestering atmospheric carbon dioxide [47]. The analysis of variance showed that only in OF was soil TOC content under T. sphaerococcum significantly lower than under T. persicum. The $\eta^{2}$ measure of effect size showed that wheat cultivation accounted for $57.47 \%$ (OF) and $68 \%$ (CF) of the influence on TOC content (Figure 1A,B). The significantly highest content of TOC (on average $9.27 \mathrm{~g} \mathrm{~kg}^{-1}, \pm 0.442$ ) was found in soil of sowing density $400 \mathrm{grains} \mathrm{m}^{-2}$ in $\mathrm{OF}$, as compared to $11.08 \mathrm{~g} \mathrm{~kg}^{-1}( \pm 0.424)$ with a density of 500 grains $\mathrm{m}^{-2}$ in CF. 
Table 2. Content of total organic carbon (TOC) and glomalin (easily extractable glomalin-related soil protein (EEGRSP)) in the soil.

\begin{tabular}{|c|c|c|c|c|c|c|}
\hline \multirow{4}{*}{$\begin{array}{c}\text { Sowing } \\
\text { Density } \\
\text { (II) }\end{array}$} & \multicolumn{3}{|c|}{ Organic Farming (OF) } & \multicolumn{3}{|c|}{ Conventional Farming (CF) } \\
\hline & \multicolumn{6}{|c|}{ Species (I) } \\
\hline & T. sphaerococcum & T. persicum & Mean & T. sphaerococcum & T. persicum & Mean \\
\hline & \multicolumn{6}{|c|}{ Total Organic Carbon $\left(\mathrm{g} \mathrm{kg}^{-1}\right)$} \\
\hline 400 & $9.53 \pm 0.576$ & $8.96 \pm 0.050$ & $9.27 \pm 0.403^{\mathrm{A}}$ & $9.41 \pm 0.009^{a}$ & $9.14 \pm 0.032^{b}$ & $9.27 \pm 0.191^{C}$ \\
\hline 500 & $7.32 \pm 0.065^{b}$ & $9.53 \pm 0.036^{a}$ & $8.44 \pm 1.563^{B}$ & $11.38 \pm 0.018^{\mathrm{a}}$ & $10.78 \pm 0.024^{b}$ & $11.08 \pm 0.424^{\mathrm{A}}$ \\
\hline 600 & $6.94 \pm 0.013$ & $7.62 \pm 0.016$ & $7.28 \pm 0.481^{C}$ & $9.83 \pm 0.023^{b}$ & $11.56 \pm 0.039^{a}$ & $10.70 \pm 1.223^{\mathrm{B}}$ \\
\hline \multirow[t]{2}{*}{ mean } & $7.95 \pm 1.142$ & $8.70 \pm 0.801$ & $8.33 \pm 0.566$ & $10.20 \pm 0.847^{\mathrm{B}}$ & $10.49 \pm 1.009^{\mathrm{A}}$ & $10.35 \pm 0.442$ \\
\hline & \multicolumn{6}{|c|}{ Glomalin $\left(\mathrm{g} \mathrm{kg}^{-1}\right)$} \\
\hline 400 & $0.978 \pm 0.073$ & $0.706 \pm 0.020$ & $0.841 \pm 0.192$ & $1.052 \pm 0.013$ & $0.962 \pm 0.067$ & $1.007 \pm 0.064^{\mathrm{B}}$ \\
\hline 500 & $0.839 \pm 0.103$ & $0.900 \pm 0.026$ & $0.870 \pm 0.043$ & $1.141 \pm 0.081$ & $1.224 \pm 0.188$ & $1.183 \pm 0.059 \mathrm{~A}$ \\
\hline 600 & $0.902 \pm 0.098$ & $0.861 \pm 0.062$ & $0.881 \pm 0.029$ & $1.003 \pm 0.059$ & $1.085 \pm 0.054$ & $1.044 \pm 0.058 \mathrm{AB}$ \\
\hline mean & $0.906 \pm 0.070^{\mathrm{A}}$ & $0.823 \pm 0.103^{B}$ & $0.864 \pm 0.021$ & $1.065 \pm 0.070$ & $1.090 \pm 0.131$ & $1.078 \pm 0.581$ \\
\hline
\end{tabular}

Were analyzed by two-way ANOVA for spring wheat species (I factor), and sowing density (II factor) was calculated independently for organic farming (OF) and for conventional farming (CF). Different small letters indicate comparison between species of spring wheat. Different capital letters indicate a comparison among between sowing density; \pm Standard Deviation.

Studies concerning cereal cultivation in Poland indicate concentration of GRSP in soils in the range of $0.82-4.06 \mathrm{mg} \mathrm{g}^{-1}$ under rye, $0.61-2.73 \mathrm{mg} \mathrm{g}^{-1}$ under winter wheat, and $0.62-2.19 \mathrm{mg} \mathrm{g}^{-1}$ under spring wheat, as well as strong positive Pearson's coefficient of linear correlation between GRSP and carbon content $(r=0.701)$ and GRSP and nitrogen content $(r=0.760)$ [48]. The obtained results of EEGRSP content in the soil under the two species of spring wheat within the range of $0.706( \pm 0.020)-1.224$ $( \pm 0.188) \mathrm{g} \mathrm{kg}^{-1}$ coincide with the abovementioned research. The concentration of glomalin in the soil from the fields cultivated under the system of OF was influenced significantly by wheat species (Table 2). In CF, the significant difference resulted from sowing density and interaction between wheat species and sowing density. Furthermore, the $\mathrm{OF}$, was characterized by a positive relation between EEGRSP and activities of AlP and AcP $(r=0.397 ; p=0.05510$ and $r=0.462 * ; p=0.02290$, respectively, Table 3). Correlations between EEGRSP and other soil enzymes vary widely; for example, for soil protease and $\beta$-glucosidase, Pearson correlation coefficients were determined as -0.899 and 0.761 , respectively [49]. A positive correlation was also revealed between EEGRSP and TOC $\left(r=0.613^{* * *}\right.$; $p=0.00140$, Table 4) in the system of CF, which corresponds to other studies that indicate a similar relation $[32,50]$.

The absorbable forms of nutrients are the most important soil fraction in determining plant yields. The analysis of variance showed that experiment factors significantly influenced bioavailable macronutrients (Table 5). The highest content of $\mathrm{P}\left(50.51 \mathrm{mg} \mathrm{kg}^{-1}, \pm 6.642\right), \mathrm{K}\left(91.55 \mathrm{mg} \mathrm{kg}^{-1}, \pm 14.45\right)$, and $\mathrm{Mg}\left(14.82 \mathrm{mg} \mathrm{kg}^{-1}, \pm 2.579\right)$ was obtained for the cultivation of T. sphaerococcum, both in OF and CF. $P$ content was lower at the density of 600 grains than $200 \mathrm{~m}^{-2}$ and $400 \mathrm{~m}^{-2}$ grains (Table 5). In addition, the highest content of $\mathrm{K}$ (on average $\left.99.95 \mathrm{mg} \mathrm{kg}^{-1}, \pm 6.025\right)$ and $\mathrm{Mg}\left(16.17 \mathrm{mg} \mathrm{kg}^{-1}, \pm 12.24\right.$ ) was found with densities of up to 400 grains $\mathrm{m}^{-2}$.

The crop canopy density is the basic agrotechnical factor shaping not only plant development and yield, but also soil properties. According to Hinsinger [51], plants release various secretions into the soil through the root system, which influence the transformation of nutrients. Their uptake and accumulation by plants varies by species and even by variety. Optimal sowing density depends on plant requirements and habitat conditions. Too high a sowing density may lead to plants competing for nutrients and depleting them from the soil. Analysis of $\eta^{2}$ coefficients indicated that it is mainly sowing density that explains the variability of $\mathrm{K}(82 \%), \mathrm{Mg}(61.5 \%)$ in OF (Figure $1 \mathrm{~A})$ and $\mathrm{P}(61.1 \%)$, $\mathrm{K}(75.5 \%), \mathrm{Mg}(52.3 \%)$ in CF (Figure 1B). 
Table 3. Relationship between selected soil properties in organic farming (OF) $(n=24)$.

\begin{tabular}{|c|c|c|c|c|c|}
\hline \multicolumn{2}{|c|}{ Variable } & \multirow{2}{*}{ Equation } & \multirow{2}{*}{$r$} & \multirow{2}{*}{$R^{2}$} & \multirow{2}{*}{$p$} \\
\hline Dependent & Independent & & & & \\
\hline $\mathrm{TZn}$ & $\mathrm{pH} \mathrm{KCl}$ & $y=16.429+1.239 x$ & $0.725^{* * *}$ & 0.526 & 0.00006 \\
\hline $\mathrm{AZn}$ & $\mathrm{pH} \mathrm{KCl}$ & $y=-0.695+1.249 x$ & $0.496 * *$ & 0.247 & 0.01360 \\
\hline AlP & $\mathrm{pH} \mathrm{KCl}$ & $y=-0.298+0.135 x$ & $0.529 * * *$ & 0.208 & 0.00780 \\
\hline $\mathrm{AcP}$ & $\mathrm{pH} \mathrm{KCl}$ & $y=-1.141+0.473 x$ & $0.716^{* * *}$ & 0.513 & 0.00008 \\
\hline $\mathrm{TZn}$ & Clay & $y=19.174+0.822 x$ & $0.427^{* *}$ & 0.182 & 0.03760 \\
\hline $\mathrm{TZn}$ & TOC & $y=26.548-0.464 x$ & $-0.896^{* * *}$ & 0.803 & 0.00001 \\
\hline AZn & TOC & $y=9.673-0.488 x$ & $-0.640^{* * *}$ & 0.409 & 0.00008 \\
\hline $\mathrm{ACu}$ & TOC & $y=4.602-0.328 x$ & $-0.695^{* * *}$ & 0.483 & 0.00020 \\
\hline Cu plant & TOC & $y=-3.049+0.838 x$ & $0.769^{* * *}$ & 0.592 & 0.00001 \\
\hline $\mathrm{AlP}$ & TOC & $\mathrm{y}=0.788-0.050 \mathrm{x}$ & $-0.674^{* * *}$ & 0.454 & 0.00030 \\
\hline $\mathrm{AcP}$ & TOC & $y=2.652-0.168 x$ & $-0.842^{* * *}$ & 0.708 & 0.00001 \\
\hline AlP & $\mathrm{P}$ & $y=0.202+0.003 x$ & $0.476^{* *}$ & 0.226 & 0.01880 \\
\hline Insects & $\mathrm{Cu}$ plant & $y=281.54-29.612 x$ & $-0.771^{* * *}$ & 0.595 & 0.00001 \\
\hline AlP & AZn & $y=0.092+0.049 x$ & $0.499 * *$ & 0.249 & 0.01310 \\
\hline $\mathrm{AcP}$ & AZn & $y=0.318+0.167 x$ & $0.637^{* * *}$ & 0.405 & 0.00008 \\
\hline AlP & $\mathrm{ACu}$ & $y=0.091+0.492 x$ & $0.499 * *$ & 0.249 & 0.01310 \\
\hline $\mathrm{AcP}$ & $\mathrm{ACu}$ & $y=0.318+0.167 x$ & $0.637^{* * *}$ & 0.405 & 0.00080 \\
\hline AlP & EEGGRSP & $y=0.083+0.332 x$ & 0.397 & 0.158 & 0.05510 \\
\hline $\mathrm{AcP}$ & EEGGRSP & $y=0.373+1.030 x$ & $0.462 *$ & 0.213 & 0.02290 \\
\hline
\end{tabular}

Table 4. Relationship between selected soil properties in conventional farming (CF) $(n=24)$.

\begin{tabular}{|c|c|c|c|c|c|}
\hline \multicolumn{2}{|c|}{ Variable } & \multirow{2}{*}{ Equation } & \multirow{2}{*}{$r$} & \multirow{2}{*}{$R^{2}$} & \multirow{2}{*}{$p$} \\
\hline Dependent & Independent & & & & \\
\hline $\mathrm{P}$ & $\mathrm{pH} \mathrm{KCl}$ & $y=-1071.1+155.8 x$ & $0.573^{* * *}$ & 0.328 & 0.00340 \\
\hline K & $\mathrm{pH} \mathrm{KCl}$ & $y=-4198.7+581.6 x$ & $0.720 * * *$ & 0.519 & 0.00007 \\
\hline $\mathrm{Mg}$ & $\mathrm{pH} \mathrm{KCl}$ & $y=-3009.8+425.6 x$ & $0.786^{* * *}$ & 0.617 & 0.00001 \\
\hline $\mathrm{TCu}$ & $\mathrm{pH} \mathrm{KCl}$ & $y=-18.614+3.291 x$ & $0.466^{* *}$ & 0.217 & 0.02180 \\
\hline $\mathrm{ACu}$ & $\mathrm{pH} \mathrm{KCl}$ & $y=-19.974-2.793 x$ & $0.416^{* *}$ & 0.173 & 0.04350 \\
\hline AZn & Clay & $y=-2.259+2.036 x$ & $0.502 * *$ & 0.252 & 0.01250 \\
\hline $\mathrm{ACu}$ & Clay & $y=-1.481+0.501 x$ & $0.579 * * *$ & 0.235 & 0.00310 \\
\hline $\mathrm{AlP}$ & Clay & $y=-0.459+0.245 x$ & $0.854^{* * *}$ & 0.730 & 0.00001 \\
\hline $\mathrm{AcP}$ & Clay & $y=0.032+0.288 x$ & $0.750^{* * *}$ & 0.562 & 0.00002 \\
\hline $\mathrm{AZn}$ & TOC & $y=1.842+0.571 x$ & $0.478^{* *}$ & 0.229 & 0.01810 \\
\hline EEGGRSP & TOC & $y=0.410+0.065 x$ & $0.613^{* * *}$ & 0.376 & 0.00140 \\
\hline AlP & AZn & $y=0.295+0.040 x$ & $0.636^{* * *}$ & 0.404 & 0.00080 \\
\hline $\mathrm{AcP}$ & $\mathrm{AZn}$ & $y=0.975+0.061 x$ & $0.647^{* * *}$ & 0.418 & 0.00060 \\
\hline AlP & $\mathrm{ACu}$ & $y=0.392+0.212 x$ & $0.727^{* * *}$ & 0.529 & 0.00006 \\
\hline
\end{tabular}


Table 4. Cont.

\begin{tabular}{|c|c|c|c|c|c|}
\hline \multicolumn{2}{|c|}{ Variable } & \multirow{2}{*}{ Equation } & \multirow{2}{*}{$r$} & \multirow{2}{*}{$R^{2}$} & \multirow{2}{*}{$p$} \\
\hline Dependent & Independent & & & & \\
\hline $\mathrm{AcP}$ & $\mathrm{ACu}$ & $y=1.078+0.376 x$ & $0.850 * * *$ & 0.723 & 0.00001 \\
\hline Insects & Cu plant & $y=14.567-0.104 x$ & $-0.468^{* *}$ & 0.219 & 0.02100 \\
\hline
\end{tabular}

Table 5. Content of available phosphorus $(\mathrm{P})$, potassium $(\mathrm{K})$, magnesium $(\mathrm{Mg})$ in soil.

\begin{tabular}{|c|c|c|c|c|c|c|}
\hline \multirow{4}{*}{$\begin{array}{l}\text { Sowing } \\
\text { Density } \\
\text { (II) }\end{array}$} & \multicolumn{3}{|c|}{ Organic Farming (OF) } & \multicolumn{3}{|c|}{ Conventional Farming (CF) } \\
\hline & \multicolumn{6}{|c|}{ Species (I) } \\
\hline & T. sphaerococcum & T. persicum & Mean & T. sphaerococcum & T. persicum & Mean \\
\hline & \multicolumn{6}{|c|}{ Phosphorus (mg kg ${ }^{-1}$ ) } \\
\hline 400 & $57.24 \pm 0.570$ & $40.72 \pm 0.987$ & $48.98 \pm 11.68^{\mathrm{A}}$ & $116.5 \pm 9.280$ & $99.91 \pm 2.436$ & $108.2 \pm 11.73^{\mathrm{A}}$ \\
\hline 500 & $50.32 \pm 1.073$ & $32.90 \pm 0.647$ & $42.61 \pm 12.32^{B}$ & $99.54 \pm 0.925$ & $93.50 \pm 1.634$ & $96.52 \pm 4.271^{B}$ \\
\hline 600 & $43.96 \pm 1.801$ & $29.50 \pm 3.011$ & $36.73 \pm 14.47^{\mathrm{C}}$ & $91.03 \pm 2.623$ & $89.74 \pm 0.543$ & $90.39 \pm 0.912^{B}$ \\
\hline \multirow[t]{2}{*}{ mean } & $50.51 \pm 6.642 \mathrm{~A}$ & $35.04 \pm 8.622^{B}$ & $42.77 \pm 6.127$ & $102.4 \pm 12.96^{\mathrm{A}}$ & $94.38 \pm 5.142^{B}$ & $98.38 \pm 9.048$ \\
\hline & \multicolumn{6}{|c|}{ Potassium $\left(\mathrm{mg} \mathrm{kg}^{-1}\right)$} \\
\hline 400 & $104.2 \pm 0.035$ & $95.68 \pm 2.298$ & $99.95 \pm 6.025^{\mathrm{A}}$ & $202.1 \pm 0.919^{\mathrm{a}}$ & $183.9 \pm 3.429^{b}$ & $192.9 \pm 12.87^{\mathrm{A}}$ \\
\hline 500 & $94.63 \pm 1.732$ & $81.38 \pm 0.742$ & $88.00 \pm 9.369^{\mathrm{B}}$ & $183.9 \pm 2.192^{\mathrm{a}}$ & $155.6 \pm 0.919^{b}$ & $169.8 \pm 20.01^{B}$ \\
\hline 600 & $75.80 \pm 3.790$ & $66.35 \pm 2.687$ & $71.08 \pm 6.682^{C}$ & $150.2 \pm 0.071^{\mathrm{a}}$ & $114.2 \pm 2.482^{b}$ & $132.2 \pm 24.46^{\mathrm{C}}$ \\
\hline \multirow[t]{2}{*}{ mean } & $91.55 \pm 14.45^{\mathrm{A}}$ & $81.13 \pm 14.67^{\text {B }}$ & $86.34 \pm 14.51$ & $178.7 \pm 26.33^{\mathrm{A}}$ & $151.3 \pm 35.06^{\mathrm{B}}$ & $164.9 \pm 30.64$ \\
\hline & \multicolumn{6}{|c|}{ Magnesium (mg kg${ }^{-1}$ ) } \\
\hline 400 & $18.45 \pm 0.636^{\mathrm{a}}$ & $13.89 \pm 0.636^{b}$ & $16.17 \pm 12.24^{\mathrm{A}}$ & $21.53 \pm 1.273$ & $18.55 \pm 4.313$ & $20.04 \pm 21.07^{\mathrm{A}}$ \\
\hline 500 & $13.22 \pm 1.980^{\mathrm{a}}$ & $11.46 \pm 4.243^{b}$ & $13.24 \pm 12.45^{B}$ & $20.03 \pm 1.344$ & $17.06 \pm 3.323$ & $18.55 \pm 21.00^{B}$ \\
\hline 600 & $12.78 \pm 0.424^{\mathrm{a}}$ & $11.28 \pm 4.596^{\mathrm{b}}$ & $12.03 \pm 10.61^{C}$ & $17.57 \pm 2.192$ & $15.61 \pm 1.556$ & $16.58 \pm 13.86^{C}$ \\
\hline mean & $14.82 \pm 2.579 \mathrm{~A}$ & $12.21 \pm 1.074^{B}$ & $13.51 \pm 1.738$ & $19.71 \pm 1.632 \mathrm{~A}$ & $17.08 \pm 1.200^{B}$ & $18.3 .9 \pm 1.417$ \\
\hline
\end{tabular}

Were analyzed by two-way ANOVA for spring wheat species (I factor), and sowing density (II factor) was calculated independently for OF and for CF. Different small letters indicate comparison between species of spring wheat. Different capital letters indicate a comparison among between sowing density; \pm Standard Deviation.
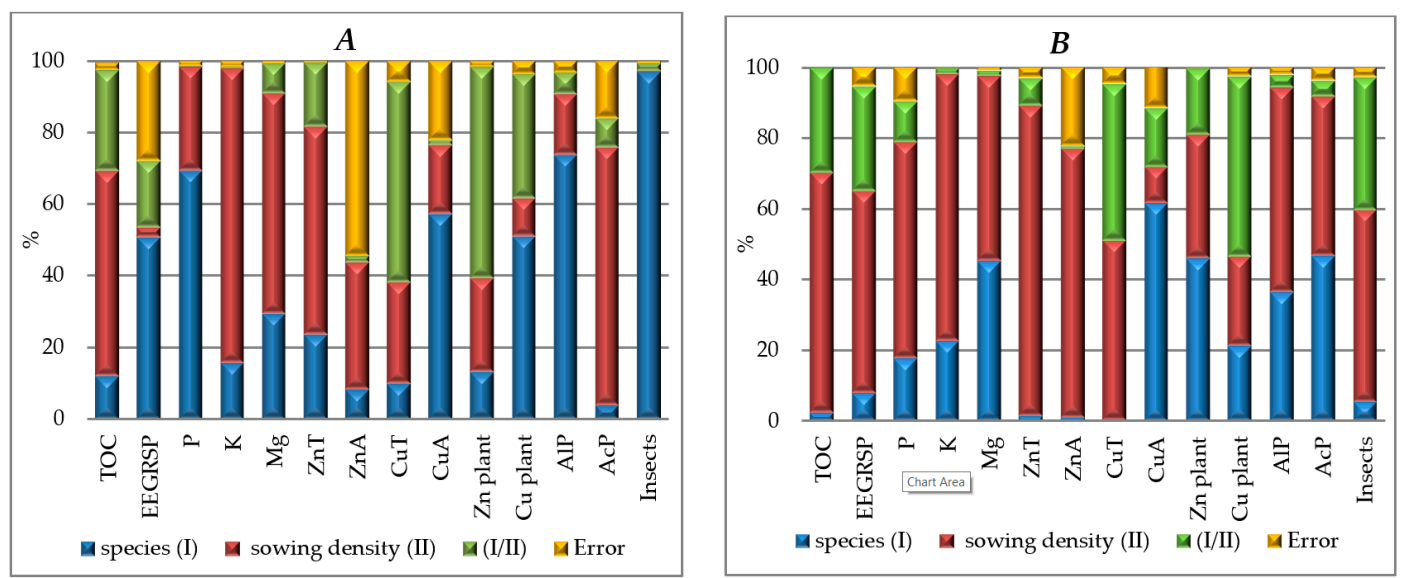

Figure 1. (A,B) Percent of observed variability $\eta^{2}$ in shaping the chemical properties in soil, $\mathrm{Zn}$ and $\mathrm{Cu}$ in wheats, activity of soil enzymes and insects, in (A) organic and (B) conventional farming.

Potassium content in soil was found to be higher with CF $\left(98.38 \mathrm{mg} \mathrm{kg}^{-1}\right.$ on average, \pm 9.048$)$ than with OF (42.77 mg kg${ }^{-1}$ on average, \pm 6.127 ) (Table 5). The $\mathrm{K}$ and $\mathrm{Mg}$ contents in the CF soil was also higher than in OF. A similar tendency was noted in works by Gosling and Shepherd [13] and Kwiatkowski et al. [18]. This is probably the result of the use of mineral fertilizers in the CF system 
increasing absorbable nutrients in the soil. The physical and chemical properties of soil tend to change very slowly and on a time scale not suited to short-term field studies [52]. Those authors found no differences in the physico-chemical soil properties between plots subjected to organic management in the previous 2-8 years and corresponding conventional plots.

In OF, the soil tested is, according to PN-R-04023 [34], class IV with a low P content, whereas in CF it is class I (very high fertility) and phosphorus fertilization was not required. According to $\mathrm{PN}-\mathrm{R}-04022$ [35], in terms of bioavailable potassium content $\left(86.34 \mathrm{mg} \mathrm{kg}^{-1}\right.$ on average, \pm 14.51$)$ the soil tested is fertility class IV (low) (OF). By contrast, the cultivation of both types of wheat in CF (on average $\left.164.9 \mathrm{mg} \mathrm{kg}^{-1}, \pm 30.64\right)$ placed the soil in class I with a very high $\mathrm{K}$ content. Magnesium content was very low (class $\mathrm{V}$ for medium soils according to agronomic category) for both cultivation systems [36]. Usually, surpluses of some nutrients block plant uptake of others, which can then be leached and affect other environmental systems, e.g., groundwater pollution. Linear correlation analysis showed that soil $\mathrm{pH}$ beneath wheat in CF significantly affects P content $\left(r=0.573^{* * *} ; p=0.00340\right), \mathrm{K}\left(r=0.720^{* * *}\right.$; $p=0.00007)$, and $\operatorname{Mg}\left(r=0.786^{* * *} ; p=0.00001\right)$ (Table 4$)$. As reported by Guo et al. [53], it is mainly soil reaction that influences the solubility of minerals, and thus their availability to plants. If the soil $\mathrm{pH}$ value falls below the optimum for a given element, the yield quickly decreases.

\subsection{Copper and Zinc Content in Soil and Wheat}

The analysis of variance showed that experiment factors significantly influenced the content of total forms of zinc under both management systems and the total content of copper in OF. In CF, only sowing density was found to affect total copper content (Table 6). The total $\mathrm{Zn}$ content was as follows: 22.14-23.57 mg kg $\mathrm{mg}^{-1}$ in OF and $29.27-32.10 \mathrm{mg} \mathrm{kg}^{-1}$ in CF, compared to $\mathrm{Cu}$ of $4.89-5.46 \mathrm{mg} \mathrm{kg}^{-1}$ in $\mathrm{OF}$ and from $5.68-6.38 \mathrm{mg} \mathrm{kg}^{-1}$ in CF (Table 6). The amount of analyzed microelements in the soil of conventional cultivation increased, but not to levels that exceeded the standards established for arable soils. All analyzed soil samples showed natural content of both $\mathrm{Zn}$ and $\mathrm{Cu}$. According to Terelak et al. [54], in agricultural soils in Poland, average content is $32.4 \mathrm{mg} \mathrm{kg}^{-1}$ for zinc and $6.50 \mathrm{mg} \mathrm{kg}^{-1}$ for copper. The natural trace element content in agricultural soils derives from the mineral composition of the parent rock, the rate and course of the soil-forming process, and human activity in terms of method and intensity of soil cultivation $[55,56]$. The $\mathrm{Cu}$ and $\mathrm{Zn}$ concentrations were largely influenced by the physical and chemical properties of the arable soils. The studies showed statistically significant relationships between total zinc content and soil $\mathrm{pH}\left(r=0.725^{* * *}, p=0.00006\right)$, the content of the clay fraction $\left(r=0.427^{* *}, p=0.0376\right)$ and TOC $\left(r=-0.896^{* * *}, p=0.00001\right)$ in OF (Table 3). However, total copper content depended significantly on soil $\mathrm{pH}\left(r=0.466^{* *}, p=0.0218\right)$ in CF (Table 4). An increase in redox potential and a decrease in reaction with low organic matter content leads to increased mobility of metals, such as lead, cadmium, zinc, copper, and mercury. The concentration of microelements in the soil also depends on the possibility of creating complex compounds with soil organic components. The formation of organometallic complexes in the soil is important in preventing toxic heavy-metal ions leaching from the soil, as well as in partially detoxifying them and limiting their uptake by plants [57].

Knowing the total content of trace elements in soils does not provide a picture of their actual 6availability to plants or their possibility of entering the biological cycle [56]. Nutrient mobility depends on granulometric composition, content of organic matter, $\mathrm{pH}$, and microbiological activity. The soil-use method and the mineral and organic fertilization applied are also very important [58]. All these factors concurrently determine the amount of elements accumulated in biological material or immobilized in soil particles [59]. The amount of microelements in the studied soils varied. The content of available forms of $\mathrm{Zn}$ and $\mathrm{Cu}$ in the soil samples lay at the median level in relation to upper and lower thresholds of permissibility, regardless of species and sowing density (Table 6). The ZnA soil content was higher in $\mathrm{CF}$ than $\mathrm{OF}$, while the opposite was true of $\mathrm{CuA}$. The analysis of variance confirmed the effect of wheat species and sowing density on the content of available forms of zinc and copper in OF. Meanwhile, in CF, it was mainly the number of plants that determined the amount 
of bioavailable forms of the studied microelements. An analysis of the $\eta^{2}$ measure of effect was used to determine the percentage share of all factors influencing the $\mathrm{Zn}$ and $\mathrm{Cu}$ content in the soil (Figure 1A,B). The results indicate that in both $\mathrm{OF}$ and $\mathrm{CF}$ it was mainly sowing density that influenced the content of TZn (58.1\% OC; $87.8 \%$ CF), AZn (35.5\% OF; $76.1 \%$ CF), TCu (28.4\% OC; $51.0 \%$ CF). Only in the case of $\mathrm{ACu}$ was the wheat species the dominant determining factor. Variation in uptake of microelements is particularly high under acidic soil conditions, as these increase solubility. In our own research, significant relationships were found between soil $\mathrm{pH}$ and the content of available forms of $\mathrm{Zn}\left(r=0.496^{* *}, p=0.0136\right)$ in OF (Table 3$)$ and the content of available forms of copper $\left(r=0.466^{* *}\right.$, $p=0.0435$ ) in CF (Table 4). A significantly negative correlation was also found between available forms of $\mathrm{Zn}$ and $\mathrm{Cu}$, as well as TOC in OF soils $\left(r=-0.640^{* * *}, p=0.00008\right.$ for $\mathrm{Zn}$ and $r=-0.695$ $* * *, p=0.0002$ for $\mathrm{Cu}$ ). The coefficient of determination $\left(R^{2}\right)$ showed that $41 \%$ of the variation in $\mathrm{AZn}$ and $48 \%$ in $\mathrm{ACu}$ depends on TOC content. The linear regression equation shows that as the TOC content increases by $1 \mathrm{~g} \mathrm{~kg}^{-1}$, AZn content decreases by $0.409 \mathrm{mg} \mathrm{kg}^{-1}$, and ACu content by $0.483 \mathrm{mg} \mathrm{kg}^{-1}$. The mobility of copper is much lower than that of zinc. Copper in soil occurs mainly in combinations with organic matter, clay minerals, and in the form of low mobile sulfates, sulfides, and carbonates [60]. This element is easily absorbed by plants in the form of $\mathrm{Cu}^{2+}$ ions or chelates. The organic substance has a particularly strong and high sorption capacity for copper. With copper, humic, and fulvic acids give both soluble and insoluble compounds, depending on the degree of their saturation and reaction [61]. In CF, on the other hand, a significantly positive correlation was noted between bioavailable zinc and TOC $\left(r=0.478^{* *}, p=0.0181\right)$. Significantly positive relationships were also found between the available forms of both elements and the clay fraction $(r=0.502 * *, p=0.01250$ for $\mathrm{Zn}$ and $\left.r=0.579^{* * *}, p=0.00310 \mathrm{for} \mathrm{Cu}\right)$. The value of the coefficient of determination $\left(R^{2}\right)$ showed that only $25 \%$ of the variability in AZn and $23 \%$ of ACu was related to the size of the clay fraction (Table 4).

The bioavailability coefficient $\left(A F_{Z n}\right)$ calculated for zinc was in a range from 22.2 to $28.2 \%$. Figure 2A shows that the increase in this coefficient was influenced by sowing density, regardless of the management system. Its value was not influenced by wheat species. By contrast, the coefficient was found to increase with sowing density, regardless of the type of farm (Figure 2A). A different relationship was noted in the case of $A F_{C u}$. Figure $2 \mathrm{~B}$ shows that both wheat species and sowing density influenced the coefficient's value. The highest $A F_{C u}$ value of $49.2 \%$ was recorded for Triticum sphaerococcum with a sowing density of 600 grains $\mathrm{m}^{-2}$.
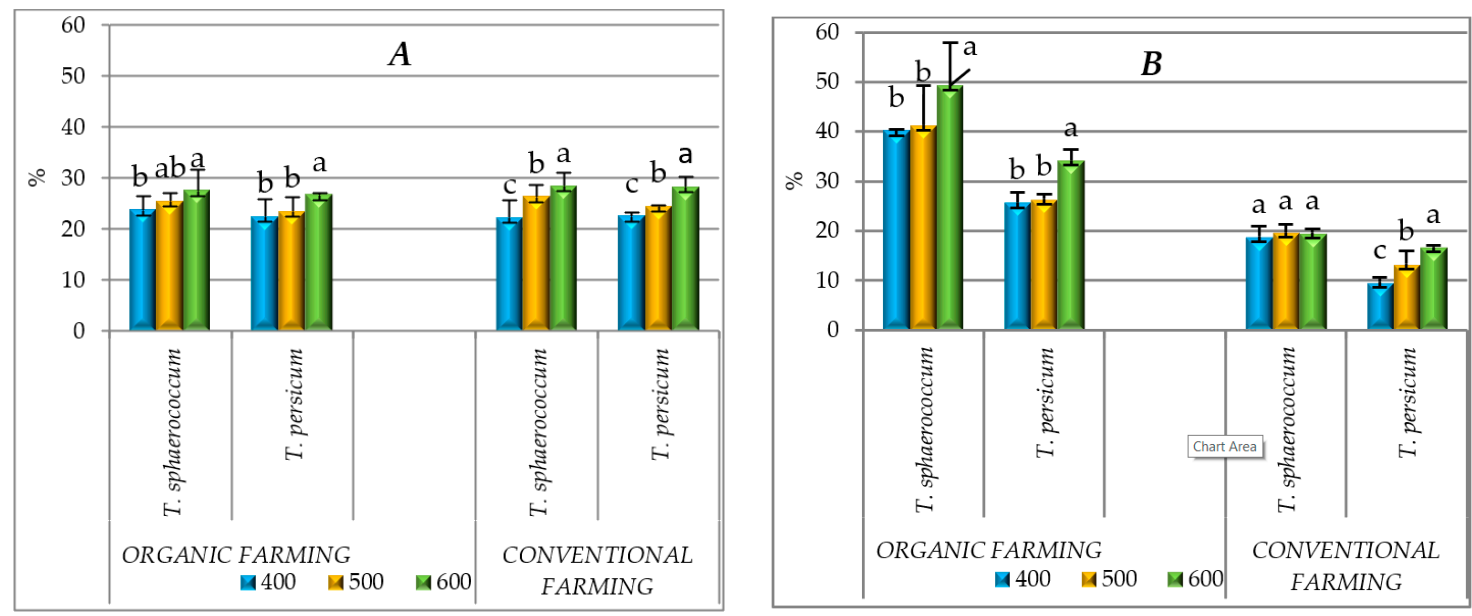

Figure 2. (A,B). Availability factors $(A F \%)$ for $\mathrm{Zn}(\mathbf{A})$ and for $\mathrm{Cu}(\mathbf{B})$. (Were analyzed by two-way ANOVA for spring wheat species (I factor), and sowing density (II factor) was calculated independently for OF and for CF. Different small letters indicate comparison between species of spring wheat; Standard Deviation). 
Table 6. Contents of $\mathrm{Zn}, \mathrm{Cu}$ in the soil and plants.

\begin{tabular}{|c|c|c|c|c|c|c|}
\hline \multirow{4}{*}{$\begin{array}{l}\text { Sowing } \\
\text { Density } \\
\text { (II) }\end{array}$} & \multicolumn{3}{|c|}{ Organic Farming (OF) } & \multicolumn{3}{|c|}{ Conventional Farming (CF) } \\
\hline & \multicolumn{6}{|c|}{ Species (I) } \\
\hline & T.sphaerococcum & T. persicum & Mean & T. sphaerococcum & T. persicum & Mean \\
\hline & \multicolumn{6}{|c|}{ Total Zn (mg kg-1) } \\
\hline 400 & $22.14 \pm 0.10^{b}$ & $22.25 \pm 0.01^{\mathrm{a}}$ & $22.19 \pm 0.08^{C}$ & $30.41 \pm 0.21^{\mathrm{a}}$ & $29.27 \pm 0.48^{b}$ & $29.84 \pm 0.81^{\mathrm{B}}$ \\
\hline 500 & $23.23 \pm 0.00^{\mathrm{a}}$ & $22.47 \pm 0.02^{b}$ & $22.86 \pm 0.54^{\mathrm{B}}$ & $29.74 \pm 0.04$ & $30.02 \pm 0.05$ & $29.88 \pm 0.20^{\mathrm{B}}$ \\
\hline 600 & $23.57 \pm 0.02^{\mathrm{a}}$ & $22.70 \pm 0.01^{\mathrm{b}}$ & $23.13 \pm 0.62^{\mathrm{A}}$ & $32.06 \pm 0.03$ & $32.10 \pm 0.12$ & $32.08 \pm 0.03^{\mathrm{A}}$ \\
\hline \multirow[t]{2}{*}{ mean } & $22.98 \pm 0.75^{\mathrm{A}}$ & $22.47 \pm 0.23^{B}$ & $22.72 \pm 0.48$ & $30.73 \pm 1.20^{\mathrm{A}}$ & $30.46 \pm 3.64^{\mathrm{B}}$ & $30.60 \pm 1.28$ \\
\hline & \multicolumn{6}{|c|}{ Total $\mathrm{Cu}\left(\mathrm{mg} \mathrm{kg}^{-1}\right)$} \\
\hline 400 & $5.17 \pm 0.02^{b}$ & $5.60 \pm 0.01^{\mathrm{a}}$ & $5.38 \pm 0.30^{\mathrm{A}}$ & $6.30 \pm 0.02$ & $6.38 \pm 0.06$ & $6.34 \pm 0.81^{\mathrm{A}}$ \\
\hline 500 & $5.25 \pm 0.00^{\mathrm{a}}$ & $4.89 \pm 0.07^{b}$ & $5.07 \pm 0.25^{C}$ & $6.15 \pm 0.05^{\mathrm{a}}$ & $5.68 \pm 0.05^{b}$ & $5.92 \pm 0.33^{C}$ \\
\hline 600 & $5.07 \pm 0.03^{b}$ & $5.46 \pm 0.13^{\mathrm{a}}$ & $5.27 \pm 0.28^{B}$ & $5.85 \pm 0.01^{b}$ & $6.19 \pm 0.03^{\mathrm{a}}$ & $6.02 \pm 0.47^{\mathrm{B}}$ \\
\hline \multirow[t]{2}{*}{ mean } & $5.16 \pm 0.09^{B}$ & $5.32 \pm 0.38^{\mathrm{A}}$ & $5.24 \pm 0.13$ & $6.10 \pm 0.23$ & $5.34 \pm 0.29$ & $5.72 \pm 0.24$ \\
\hline & \multicolumn{6}{|c|}{ Available Zn (mg kg-1) } \\
\hline 400 & $5.23 \pm 0.61$ & $4.98 \pm 0.79$ & $5.11 \pm 0.18^{C}$ & $6.76 \pm 0.77$ & $6.63 \pm 0.25$ & $6.69 \pm 0.09^{C}$ \\
\hline 500 & $5.99 \pm 0.38$ & $5.25 \pm 0.65$ & $5.62 \pm 0.52^{B}$ & $7.82 \pm 0.68$ & $7.33 \pm 0.03$ & $7.58 \pm 0.35^{\mathrm{B}}$ \\
\hline 600 & $6.39 \pm 0.98$ & $6.05 \pm 0.10$ & $6.22 \pm 0.24^{\mathrm{A}}$ & $9.11 \pm 0.87$ & $9.06 \pm 0.64$ & $9.08 \pm 0.04^{\mathrm{A}}$ \\
\hline \multirow[t]{2}{*}{ mean } & $5.87 \pm 0.59 \mathrm{~A}$ & $5.43 \pm 0.56^{\mathrm{B}}$ & $5.65 \pm 0.13$ & $7.90 \pm 1.18$ & $7.67 \pm 1.25$ & $7.78 \pm 1.21$ \\
\hline & \multicolumn{6}{|c|}{ Available Cu (mg kg $\left.{ }^{-1}\right)$} \\
\hline 400 & $2.08 \pm 0.00$ & $1.44 \pm 0.12$ & $1.76 \pm 0.45^{\mathrm{B}}$ & $1.19 \pm 0.13^{\mathrm{a}}$ & $0.62 \pm 0.05^{b}$ & $0.90 \pm 0.40^{B}$ \\
\hline 500 & $2.17 \pm 0.40$ & $1.29 \pm 0.06$ & $1.73 \pm 0.62^{B}$ & $1.21 \pm 0.10^{\mathrm{a}}$ & $0.76 \pm 0.14^{b}$ & $0.98 \pm 0.32 \mathrm{AB}$ \\
\hline 600 & $2.50 \pm 0.44$ & $1.87 \pm 0.14$ & $2.19 \pm 0.45^{\mathrm{A}}$ & $1.15 \pm 0.05$ & $1.04 \pm 0.02$ & $1.09 \pm 0.08^{\mathrm{A}}$ \\
\hline \multirow[t]{2}{*}{ mean } & $2.25 \pm 0.22^{\mathrm{A}}$ & $1.53 \pm 0.30^{\mathrm{B}}$ & $1.89 \pm 0.26$ & $1.18 \pm 0.03^{\mathrm{A}}$ & $0.80 \pm 0.21^{\mathrm{B}}$ & $0.99 \pm 0.10$ \\
\hline & \multicolumn{6}{|c|}{$\mathrm{Zn}$ in plant $\left(\mathrm{mg} \mathrm{kg}^{-1}\right)$} \\
\hline 400 & $34.03 \pm 0.12^{b}$ & $37.17 \pm 0.79^{\mathrm{a}}$ & $35.60 \pm 2.22^{\mathrm{A}}$ & $25.39 \pm 0.45^{\mathrm{a}}$ & $21.85 \pm 0.45^{\mathrm{b}}$ & $23.62 \pm 2.50^{\mathrm{C}}$ \\
\hline 500 & $36.09 \pm 0.13^{\mathrm{a}}$ & $32.46 \pm 0.33^{b}$ & $34.27 \pm 2.57^{\mathrm{B}}$ & $36.01 \pm 0.36^{\mathrm{a}}$ & $29.46 \pm 0.36^{b}$ & $32.73 \pm 4.63^{\mathrm{A}}$ \\
\hline 600 & $28.93 \pm 0.14^{b}$ & $35.43 \pm 0.40^{\mathrm{a}}$ & $32.18 \pm 4.98^{\mathrm{C}}$ & $39.35 \pm 0.44^{\mathrm{a}}$ & $22.45 \pm 0.44^{\mathrm{b}}$ & $30.90 \pm 11.9^{\mathrm{B}}$ \\
\hline \multirow[t]{2}{*}{ mean } & $33.02 \pm 3.68^{\mathrm{B}}$ & $35.02 \pm 2.38^{\mathrm{A}}$ & $34.02 \pm 1.72$ & $33.58 \pm 7.29 \mathrm{~A}$ & $24.59 \pm 4.23^{\mathrm{B}}$ & $29.08 \pm 4.82$ \\
\hline & \multicolumn{6}{|c|}{$\mathrm{Cu}$ in plant $\left(\mathrm{mg} \mathrm{kg}^{-1}\right)$} \\
\hline 400 & $3.54 \pm 0.06^{b}$ & $4.48 \pm 0.12^{\mathrm{a}}$ & $4.01 \pm 0.66^{\mathrm{A}}$ & $4.51 \pm 0.39^{b}$ & $7.03 \pm 0.16 a$ & $5.77 \pm 1.78^{\mathrm{A}}$ \\
\hline 500 & $2.55 \pm 0.09^{b}$ & $5.89 \pm 0.45^{\mathrm{a}}$ & $4.22 \pm 2.36^{\mathrm{A}}$ & $2.10 \pm 0.09^{b}$ & $5.71 \pm 0.29^{a}$ & $3.90 \pm 2.55^{\mathrm{C}}$ \\
\hline 600 & $3.18 \pm 0.04^{b}$ & $3.57 \pm 0.34^{\mathrm{a}}$ & $3.38 \pm 0.28^{B}$ & $6.25 \pm 0.38^{a}$ & $4.56 \pm 0.31^{b}$ & $5.40 \pm 1.20^{\mathrm{B}}$ \\
\hline mean & $3.09 \pm 0.50^{B}$ & $4.64 \pm 1.17^{\mathrm{A}}$ & $3.87 \pm 0.44$ & $4.28 \pm 2.08^{B}$ & $5.76 \pm 1.23^{\mathrm{A}}$ & $5.02 \pm 0.99$ \\
\hline
\end{tabular}

Apart from the conditions related to the physical and chemical parameters of the environment, an important role modifying the cycle of elements can be attributed to biotic elements. The bioaccumulation of elements in plants, their temporary retention and re-activation are all selective [55]. The processes of bioaccumulation vertically displace soil-borne elements from lower soil levels into plant organisms. Some elements have several-fold higher contents in plants than in soil. The content of both metals in the plant varies greatly by development stage, variety, and species, as well as their environmental concentration [56]. Both $\mathrm{Zn}$ and $\mathrm{Cu}$ are essential components for normal plant development and growth. However, there is a strong antagonism in plants' uptake of these metals [57]. In general, copper lowers the $\mathrm{Zn}$ level in above-ground parts of the plant. Conversely, high doses of zinc cause copper deficiency, especially in cereals, and may reduce the yield of plants with poor supply of copper [61]. However, the correlation analysis did not confirm such relationships. Zinc was found in higher levels than copper in the analyzed plant material (Table 6). The type of wheat 
and the sowing density influenced the content of both elements in the plant. The analysis of the $\eta^{2}$ measure of effect size showed that wheat species was the main influence on zinc content in the plant (49.95\%) in CF and on copper content (51.06\%) in OF (Figure 1A,B). Meanwhile, higher levels of copper were found in T. persicum. For this variety, copper content was also seen to fall with sowing density.

\subsection{Alkaline and Acid Phosphatase Activity in Soil}

Phosphatases belong to a broad group of enzymes that catalyze the hydrolysis of organic phosphorus compounds and are used to assess the potential rate of mineralization of such compounds in soil [62]. In addition, they are responsible for the plant's management of phosphorus. The $\eta^{2}$ analysis showed that wheat species influenced AlP activity by $50.9 \%$ (OF) and $36.55 \%$ (CF). In the case of AcP, it was sowing density that most heavily determined activity ( $72 \%$ and $45.19 \%$ ) (Figure $1 \mathrm{~A}, \mathrm{~B})$. Only in OF was activity of AlP found to be significantly higher in soil under T. sphaerococcum (average $0.431 \mathrm{mMpNP} \mathrm{kg}^{-1} \mathrm{~h}^{-1}, \pm 0.058$ ) than T. persicum (average $0.304 \mathrm{mMpNP} \mathrm{kg}^{-1} \mathrm{~h}^{-1}, \pm 0.016$ ) (Table 7). AcP activity was found to be significantly higher in soil under T. sphaerococcum cultivation (in $\mathrm{OF}$ and CF). The main source of phosphatases in the soil is microorganisms, and, in the case of acid phosphatase, also plant roots. The intensity of AcP synthesis and secretion varies between species and even varieties of plants, as they activate different acid phosphatase pools to obtain mineral phosphorus from internal and external sources.

Both phosphatases were found to be more active in CF soil than in OF. Research by Lagomarsino et al. [25] also showed in conventional farming that, in soil under tomato, pea, and durum wheat, activity of acid phosphatase and arylsulfatase was higher than that of other enzymes (dehydrogenases, $\beta$-glucosidase, $N$-acetyl- $\beta$-D-glucosaminidase). The applied mineral fertilizers probably became a direct source of food for soil microorganisms, increasing their number, which additionally increased the activity of enzymes. Agrotechnical treatments in conventional tillage lead to the improvement of soil climate on the appropriate level of aeration and moisture of soil, which should increase its biochemical activity.

The paper presents negative correlations between the content of TOC in soil and the activity of AlP $\left(r=-0.674^{* * ;} ; p=0.00030\right)$ and AcP $\left(r=-0.842^{* * *} ; p=0.00001\right)$ in OF (Table 3). Earlier studies show positive correlations between these parameters [18,63]. According to Feng et al. [64], the activation of enzyme activity could accelerate the degradation rate of soil organic matter (SOM), leading to the depletion of soil organic carbon (SOC). Those authors believe that, in arable soils of low SOC content, enzyme activity may be inhibited by a lack of energy and substrates. This suggests that enzymatic activity is not a perfect reflection of SOC content. Research by Marinari et al. [65] showed that the minimum period of organic farming should be seven years. After this period, the soils achieve better physical, chemical and biological parameters. In CF, no significant correlations were found between TOC content and the activity of phosphatases. This may be due to the low share of humic substances in the soil's total organic matter content. This limits the availability of easily absorbable carbon, which affects the development of the soil microorganisms that produce these enzymes [66].

The correlation analysis showed a significant relationship between phosphorus content in the OF soil and AlP activity $\left(r=0.476^{* *} ; p=0.01880\right)$ (Table 3$)$. This suggests that this enzyme was an appropriate parameter to characterize the analyzed soils in terms of available phosphorus content, as opposed to acid phosphatase activity. However, based on the $R^{2}$ coefficient of determination, it was found that only $22.7 \%$ of $p$ determines AlP activity. Positive significant correlations in CF were obtained between clay content and the activity of both AlP $\left(r=0.854^{* * *} ; p=0.00001\right)$ and AcP $\left(r=0.750^{* * *}\right.$; $p=0.00002$ ) (Table 4). Interpretation of this phenomenon is complicated by the possible long-term occurrence of extracellular enzymes in soil in combinations with soil colloids. It is known that the substrate for phosphomonoesterases consists of organophosphorus compounds found in soil $[67,68]$. Knowing the size of these two parameters should largely allow the bioavailable phosphorus content to be estimated, which can be considered as phosphorus determined by the Egner-Riehm method. The observed changes in available phosphorus content and phosphatase activity suggest that, at a 
density of 600 grains $\mathrm{m}^{-2}$, wheat roots produce significant amounts of this enzyme under conditions of competition for $P$.

Table 7. Activity of alkaline (AlP) and acid (AcP) phosphatase in soil.

\begin{tabular}{|c|c|c|c|c|c|c|}
\hline \multirow{4}{*}{$\begin{array}{l}\text { Sowing } \\
\text { Density } \\
\text { (II) }\end{array}$} & \multicolumn{3}{|c|}{ Organic Farming (OF) } & \multicolumn{3}{|c|}{ Conventional Farming (CF) } \\
\hline & \multicolumn{6}{|c|}{ Species (I) } \\
\hline & T. sphaerococcum & T. persicum & Mean & T. sphaerococcum & T. persicum & Mean \\
\hline & \multicolumn{6}{|c|}{ Alkaline phosphatase (mM pNP kg-1 $\left.{ }^{-1}\right)$} \\
\hline 400 & $0.390 \pm 0.007$ & $0.290 \pm 0.002$ & $0.340 \pm 0.071^{\mathrm{B}}$ & $0.562 \pm 0.035$ & $0.416 \pm 0.027$ & $0.489 \pm 0.103 \mathrm{C}$ \\
\hline 500 & $0.406 \pm 0.003$ & $0.303 \pm 0.009$ & $0.354 \pm 0.073^{B}$ & $0.643 \pm 0.032$ & $0.565 \pm 0.044$ & $0.604 \pm 0.055^{\mathrm{B}}$ \\
\hline 600 & $0.498 \pm 0.045$ & $0.321 \pm 0.003$ & $0.409 \pm 0.125^{\mathrm{A}}$ & $0.781 \pm 0.006$ & $0.605 \pm 0.004$ & $0.693 \pm 0.124^{\mathrm{A}}$ \\
\hline \multirow[t]{3}{*}{ mean } & $0.431 \pm 0.058^{\mathrm{A}}$ & $0.304 \pm 0.016^{\mathrm{B}}$ & $0.368 \pm 0.036$ & $0.662 \pm 0.111$ & $0.529 \pm 0.100$ & $0.595 \pm 0.102$ \\
\hline & \multicolumn{3}{|c|}{ LSD $_{0.05}$ I-0.106; II-0.046; I/II-n.s. } & \multicolumn{3}{|c|}{ LSD $_{0.05}$ I-n.s.; II-0.059; I/II-n.s. } \\
\hline & \multicolumn{6}{|c|}{ Acid phosphatase $\left(\mathrm{mM} \mathrm{pNP} \mathrm{kg}{ }^{-1} \mathrm{~h}^{-1}\right)$} \\
\hline 400 & $1.238 \pm 0.040$ & $0.958 \pm 0.086$ & $1.098 \pm 0.677^{\mathrm{C}}$ & $1.469 \pm 0.008$ & $1.270 \pm 0.050$ & $1.369 \pm 0.141^{\mathrm{B}}$ \\
\hline 500 & $1.372 \pm 0.008$ & $1.092 \pm 0.041$ & $1.232 \pm 0.198^{\mathrm{B}}$ & $1.517 \pm 0.028$ & $1.369 \pm 0.033$ & $1.443 \pm 0.105^{\mathrm{B}}$ \\
\hline 600 & $1.542 \pm 0.056$ & $1.373 \pm 0.028$ & $1.458 \pm 1.090^{\mathrm{A}}$ & $1.587 \pm 0.022$ & $1.500 \pm 0.010$ & $1.543 \pm 0.062^{\mathrm{A}}$ \\
\hline mean & $1.384 \pm 0.845$ & $1.141 \pm 0.596$ & $1.262 \pm 0.182$ & $1.524 \pm 0.059^{\mathrm{A}}$ & $1.379 \pm 0.115^{\mathrm{B}}$ & $1.452 \pm 0.087$ \\
\hline
\end{tabular}

The correlation results revealed a significant positive relationship between soil $\mathrm{pH}$ and the activity of both AlP ( $\left.r=0.529^{* *} ; p=0.00780\right)$ and AcP $\left(r=0.716^{* *} ; p=0.00008\right)$ (Table 3$)$. Each enzyme has its own $\mathrm{pH}$ for optimal activity, and phosphatases differ from other enzymes in having a wide $\mathrm{pH}$ range ( $\mathrm{pH}$ 8-10 for $\mathrm{AlP}$ and $\mathrm{pH} 4-6$ for $\mathrm{AcP}$ ) and sensitivity to this parameter. Statistical analysis also showed a positive correlation between clay content and both AlP $\left(r=0.854^{* * *} ; p=0.00001\right)$ and AcP $(r=0.750 * * * ; p=0.00002)$ (Table 4$)$. The content of clay fractions determined $73 \%$ and $56 \%$, respectively, of the activity of the two phosphatases. The regression equation showed that a $1 \%$ increase in clay content increased AlP by $0.245 \mathrm{mMpNP} \mathrm{kg}^{-1} \mathrm{~h}^{-1}$ and AcP by $0.288 \mathrm{mMpNP} \mathrm{kg}^{-1} \mathrm{~h}^{-1}$. Both in OF and in $\mathrm{CF}$, significant positive correlations were obtained between the content of available forms of $\mathrm{Cu}$ and $\mathrm{Zn}$ and the activity of soil phosphomonoesterases (Tables 3 and 4). The presence of phosphorus in the soil is an important factor limiting heavy-metal uptake in plants, because with a higher content of its easily soluble forms, poorly soluble phosphates of, for example, zinc, cadmium, lead and copper may precipitate. However, it should be emphasized that in the present tests the permissible $\mathrm{Zn}$ and $\mathrm{Cu}$ contents are not exceeded. This indicates their natural accumulation in the soil, which did not inhibit the tested hydrolytic enzymes. It is also known that, in low concentrations, heavy metals are activators for many enzymes.

\subsection{Evaluation of Insect Numbers}

In the plots with spring wheat grown organically, in the beginning of the flowering phase an average of 167 insects $( \pm 42.760)$ were caught, compared to only 91.8 insects $( \pm 7.362)$ for CF (Figure 3$)$. The greater number of insects on OF cereals is caused by the limitations in using methods for regulating the number of the phytophages that feed on them [69]. It was found, for both organic and conventionally cultivated wheat, that significantly more insects were caught from T. sphaerococcum than from T. persicum (respectively: for OF, 208.3 and 125.8 ind.; and for CF, 93 and 90 ind.). Insects prefer a higher density of organically grown spring wheat (500 and 600 grains $\mathrm{m}^{-2}$ ), while, on CF plants, they prefer an average density of spring wheat of 500 grains $\mathrm{m}^{-2}$. 


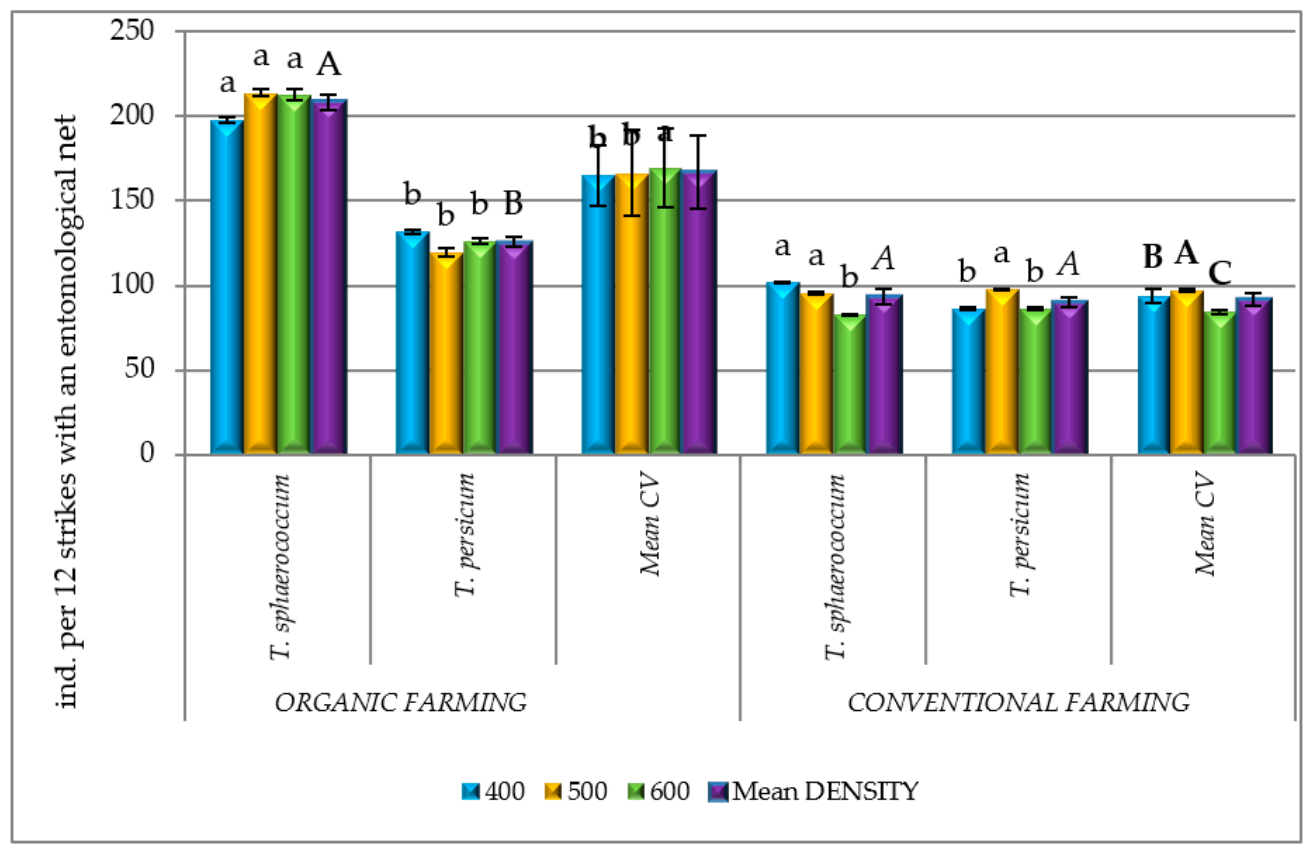

Figure 3. Number of insects (were analyzed by two-way ANOVA for spring wheat species (I factor), and sowing density (II factor) was calculated independently for OF and for CF. Different small letters indicate comparison between species of spring wheat; Different capital letters indicate comparison between sowing density; Standard Deviation, CV-cultivars).

The $\eta^{2}$ measure of effect size was used to determine the percentage share of experiment factors on the number of insects (Figure 1A,B). The results showed that the number of insects caught from plants in OF depended $97 \%$ on factor I (spring wheat species), and, in CF, $54 \%$ on factor II (wheat sowing density). Taking into account the fact that no chemical control of insect number was applied for the OF, only the plants' genetic features could effectively affect the insects [70]. Meanwhile, for CF, chemical protection measures balanced the importance of both experimental factors, even slightly in favor of canopy density. Lower sowing density improves air circulation, which reduces humidity within the canopy. Lower humidity is more favorable for numerous plant pests (especially for Thysanoptera and Heteroptera) [71,72].

The linear correlation analysis showed that, in the case of spring wheat cultivation in both OF and $\mathrm{CF}$, the number of insects was significantly inversely proportional to the copper content in the plant (respectively: $r=-0.771^{* * *} ; p=0.00001$; and $r=-0.468^{* *} ; p=0.02100$ ) (Tables 3 and 4 ). The coefficient of determination $R^{2}$ showed that the number of insects depended $59 \%$ and $42 \%$ on copper content in the wheat. The linear regression equation shows that a $1 \mathrm{mg} \mathrm{kg}^{-1}$ increase in copper in wheat saw the number of insects fall by 29.6 ind. in OF, but only by 0.104 ind. in CF. Zinc content did not significantly affect the number of insects. Similar information is provided by Mogren and Trumble [20], who claim that metals regulate the physiology, growth and development of insects. Some species show a tendency to increase locomotory behaviors to escape from locations with elevated metal pollution, while other species remain and greatly decrease all movements unrelated to feeding. But the knowledge of the effects of these pollutants at the bottom of the food web will be critical to understanding the true impact of metal contamination and to the potential reconstruction of damaged ecosystems.

Principal Component Analysis ( $P C A$ ) was performed to determine the mutual relations between the studied parameters in the two cultivation systems. It reduced the number of variables and detected general patterns in the relationships between variables, allowing the studied objects defined by those variables to be described and classified. The scatter plots of loadings for PC1 and PC2 illustrate which variables are important characteristics of the wheat and soil under two species wheats with different sowing density from organic (Figure 4A) and conventional (Figure 4B) farming system, 
respectively. Figure $4 \mathrm{~A}$ shows that the two main hypothetical reasons for variability in $\mathrm{OF}(P C 1, P C 2)$ together accounted for $72.15 \%$ of this change. The first principal component provides $40.47 \%$ of the information about soil properties contained in the input variables. Most of the variances included in the first component (PC1) correlated negatively with $\mathrm{pH}(-0.783)$, TZn (-0.927), AZn (-0.732), $\mathrm{ACu}(-0.760)$, AlP (-0.793), and AcP (-0.961) and positively with TOC content (0.905). According to Ferraz et al. [73], TOC is one of the main parameters in the evaluation of soil quality and had a strong effect on the physical, chemical and biological characteristics of the soil. The second principal component (PC2) accounts for $31.68 \%$ of the data variance. It correlated negatively with $\mathrm{P}(-0.977)$, $\mathrm{K}(-0.787), \mathrm{Mg}(-0.916)$, and insects $(-0.768)$ (Figure $4 \mathrm{~A})$.

$A$

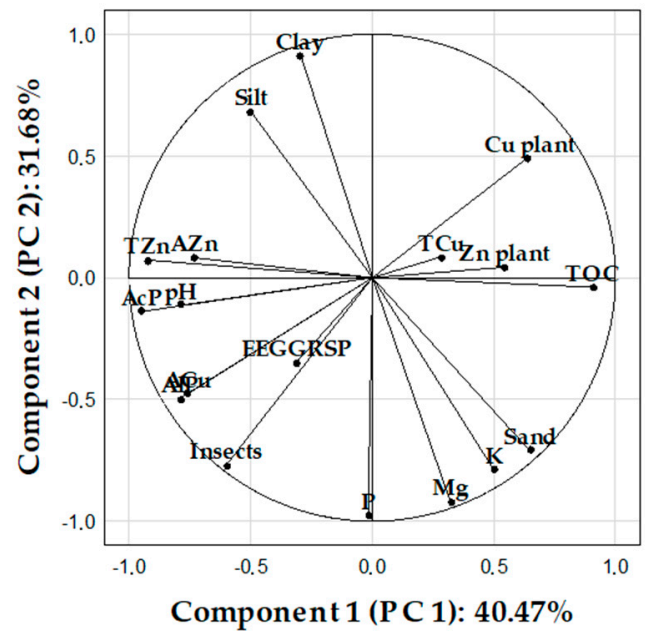

$B$

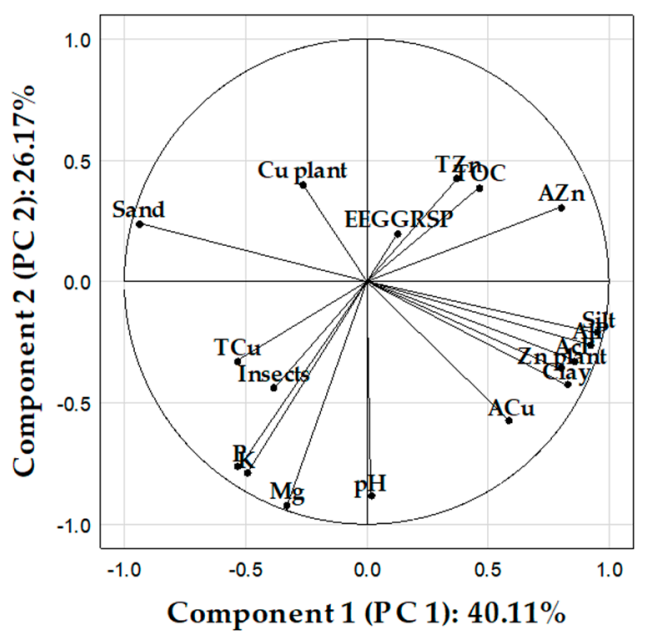

Figure 4. (A,B) Configuration of variables in the system of the first two axes $P C 1$ and $P C 2$ of principal components ((A) —organic farming, (B) — conventional farming).

The PCA eigenvalues for CF indicate that the first two principal components accounted for $66.28 \%$ of the variance (PC1: $40.11 \%, P C 2: 26.17 \%$ ). Content of silt, content of clay, AZn, AlP activity, and AcP activity were significantly positively correlated with the results of $P C 1$, at $(0.954),(0.825),(0.801)$, (0.922), and (0.857), respectively (Figure $4 \mathrm{~B})$. In contrast, the results of $P C 2$ were significantly negatively correlated with the $\mathrm{pH}$ of $\mathrm{KCl}$ in the soil $(-0.885)$ and the content of $\mathrm{P}(-0.767), \mathrm{K}(-0.793)$ and $\mathrm{Mg}$ $(-0.921)$ (Figure 4B). According Liu et al. [74], these factors can be considered strong $(>0.75)$.

Extraction of the two components with cumulative explained variance of $72.15 \%$ (for $\mathrm{OF}$ ) and $66.28 \%$ (for CF) suggests that a two factor solution would be adequate for the study [75]. The use of the PCA is important in the field of the cultivation of primary wheats because it can identify soil, plant, and insect variables that can be discarded to remove repetitive and difficult-to-measure information. According to Ghaemi et al. [76], PCA is found, therefore, to be a suitable method for selecting more effective indicators, which have key roles in soil sustainability.

\section{Conclusions}

The conducted research aimed to investigate the effect that cultivating two ancient wheat species in different sowing densities in both OF and CF had in changing chemical and enzymatic parameters in soil. At the same time, the total copper and zinc contents in wheat were assessed, as well as the influence of these microelements on insect abundance.

The density of 400 grains $\mathrm{m}^{-2}$ were associated with relatively high levels of available $\mathrm{P}, \mathrm{K}$, and $\mathrm{Mg}$ in soil, both in organic and conventional farming. Meanwhile, a density of 600 grains $\mathrm{m}^{-2}$ increased the activity of soil phosphatases. In both systems, wheat species determined soil chemical properties and phosphatase activity to a lesser extent. T. sphaerococcum had a more favorable effect on the tested soil parameters than did T. persicum. 
The soils of the conventional system were characterized by more favorable chemical properties ( $\mathrm{pH}, \mathrm{TOC}$, EEGRSP, $\mathrm{P}, \mathrm{K}, \mathrm{Mg}$, TZn, TCu) and biochemical properties (AlP, AcP) than the organic system. The activity of soil phosphatases in OF correlated negatively with total organic carbon and positively with $\mathrm{pH}$. After three years of field research, the soil's total organic carbon was found to be depleted in both organic and CF. The cultivation of wheat in $\mathrm{OF}$ reduced the content of available $\mathrm{P}, \mathrm{K}$ and $\mathrm{Mg}$ in soil. These soils can be placed in class IV (low P and K) and class V-very low Mg content. Therefore, it is recommended that additional treatments enriching the soil with these macroelements be used, and in particular the use of additional organic or natural fertilization. A relationship was established between the content of glomalin in the soil and TOC and the activity of both tested enzymes. Natural total zinc and copper contents were found in the analyzed soil material. The content of bioavailable forms of microelements was at average levels in relation to the threshold numbers. The analysis of variance confirmed the effect of wheat species and sowing density on the content of both elements in soils and in plants. Similar relationships were noted in the measure of effect size.

Regardless of the cultivation system of the host plant, insects chose T. sphaerococcum more often than T. persicum. They preferred plants grown in the OF system compared to CF, with a tendency for infestation to be greater in plants sown with a larger density. It was noted that number of insects correlated negatively with copper content in the plant, which was especially strongly visible for wheat in OF. No such effect was found for plants' Zn content.

Author Contributions: Conceptualization, M.S., J.L., and R.L., methodology, J.L., A.B., R.L., P.W., and M.S.; software, A.B., J.L.; R.L.; formal analysis, J.L., A.B., R.L., P.W., investigation, J.L., A.B., R.L., P.W., J.P., E.W., and M.S.; resources, M.S. and J.L., data curation, J.L., A.B., R.L., P.W., J.P., E.W., and M.S., writing-original draft preparation, J.L., A.B., R.L., and P.W., writing—review and editing, J.L., A.B., R.L., P.W., J.P., E.W., and M.S.; visualization, J.L. and A.B. supervision, M.S. and J.L., project administration, M.S.; funding acquisition, M.S. All authors have read and agreed to the published version of the manuscript.

Funding: "European Agricultural Fund for Rural Development: Europe investing in rural areas". The publication co-financed from the European Union funds under the COOPERATION of the Rural Development Programme for 2014-2020. The Managing Authority of the Rural Development Programme for 2014-2020-the Minister of Agriculture and Rural Development.

Conflicts of Interest: The authors declare no conflict of interest.

\section{References}

1. Cox, W.; Cherney, J.; Sorrells, M. Organic compared with conventional wheat had competitive yields during the early years of organic farming in the northeast USA. Agronomy 2019, 9, 380. [CrossRef]

2. Baker, B.P.; Benbrook, C.M.; Groth, E., III; Benbrook, K.L. Pesticide residues in conventional, integrated pest management (IPM)-grown and organic foods: Insights from three US data sets. Food Addit. Contam. 2002, 19, 427-446. [CrossRef] [PubMed]

3. Lampkin, N.H. Organic Farming, 2nd ed.; Old Pond Publishing: Ipswich, UK, 2002.

4. Hansen, A.L. The Organic Farming Manual: A Comprehensive Guide to Starting and Running a Certified Organic Farm; Storey Books: North Adams, MA, USA, 2010.

5. Cooper, J.; Sanderson, R.; Cakmak, I.; Ozturk, L.; Shotton, P.; Carmichael, A.; Sadrabadi, H.R.; Tetard-Jones, C.; Volakakis, N.; Eyre, M.; et al. Effect of organic and conventional crop rotation, fertilization, and crop protection practices on metal contents in wheat (Triticum aestivum). J. Agric. Food Chem. 2011, 59, 4715-4724. [CrossRef] [PubMed]

6. Van Bueren, E.T.L.; Jones, S.S.; Tamm, L.; Murphy, K.M.; Myers, J.R.; Leifert, C. The need to breed crop varieties suitable for organic farming, using wheat, tomato and broccoli as examples: A review. NJAS Wagening. J. Life Sci. 2011, 58, 193-205. [CrossRef]

7. Głodowska, M.; Gałąka, A. Impact of organic farming on natural environment within the concept of sustainable development. Village Agric. 2017, 2, 147-165.

8. Jaskulska, I.; Gałązka, A.; Jaskulski, D. Strip-till as a means of decreasing spatial variability of winter barley within a field scale. Acta Agric. Scand. Sect. B Soil Plant Sci. J. Impact Factor 2019, 69, 516-527. [CrossRef]

9. Komorowska, G. Importance of organig farming in Poland. Rocz. Nauk. 2015, 17, 119-126.

10. Luty, L. Rozwój rolnictwa ekologicznego na świeci. Wiadomości Stat. 2016, 656, 79-92. 
11. European Parliament; European Council. Regulation (EU) 2018/848 of the European Parliament and of the Council of 30 May 2018 on Organic Production and Labelling of Organic Products and Repealing Council Regulation (EC); No. 834/2007; European Parliament: Strasbourg, France; European Council: Brussels, Belgium, 2018.

12. Gosling, P.; Shepherd, M. Long-term changes in soil fertility in organic arable farming systems in England, with particular reference to phosphorus and potassium. Agric. Ecosyst. Environ. 2005, 105, 425-432. [CrossRef]

13. Mason, H.E.; Spanner, D. Competitive ability of wheat in conventional and organic management systems: A review of the literature. Can. J. Plant Sci. 2006, 86, 333-343. [CrossRef]

14. Poutala, R.T.; Korva, J.; Varis, E. Spring wheat cultivar performance in ecological and conventional cropping systems. J. Sustain. Agric. 1993, 3, 63-83. [CrossRef]

15. Fess, T.L.; Benedito, V.A. Organic versus conventional cropping sustainability: A comparative system analysis. Sustainability 2018, 10, 272. [CrossRef]

16. Średnicka-Tober, D.; Obiedzińska, A.; Kazimierczak, R.; Rembiałkowska, E. Environmental impact of organic vs. conventional agriculture-A review. J. Res. Appl. Agric. Eng. 2016, 61, 204-211.

17. Kwiatkowski, C.A.; Harasim, E.; Feledyn-Szewczyk, B.; Antonkiewicz, J. Enzymatic activity of loess soil in organic and conventional farming systems. Agriculture 2020, 10, 135. [CrossRef]

18. Van Gestel, C.A.M. Physico-chmical and biological parameters determine metal bioavailability in soils. Sci. Total Environ. 2008, 406, 385-394. [CrossRef]

19. Mogren, C.L.; Trumble, J.T. The impacts of metals and metalloids on insect behawior. Entomol. Exp. Appl. 2010, 135, 1-17. [CrossRef]

20. Jensen, P.; Trumble, J.T. Ecological consequences of bioavailability of metals and metalloids in insects. Recent Res. Dev. Entomol. 2003, 42, 1-17.

21. Kosiorek, M. The Importance of Zinc, Copper, Molybdenum and Manganese in Crop Production; Skoczko, O., Piekutin, J., Dąbrowska, K., Trybułowski, Ł., Eds.; Oficyna Wydawnicza Politechniki Białostockiej: Białystok, Poland, 2016; Volume 22, pp. 273-295.

22. Hladun, K.R.; Parker, D.R.; Trumble, J.T. Cadmium, copper, and lead accumulation and bioconcentration in the vegetative and reproductive organs of Raphanus sativus: Implications for plant performance and pollination. J. Chem. Ecol. 2015, 41, 386-395. [CrossRef]

23. Behmer, S.T.; Lloyd, C.M.; Raubenheimer, D.; Stewart-Clark, J.; Knight, J.; Leighton, R.S.; Harper, F.A.; Snith, J.A.C. Metal hypperaccumulation in plants: Mechanisms of defence against insect herbivores. Funct. Ecol. 2005, 19, 55-66. [CrossRef]

24. Lagomarsino, A.; Moscatelli, M.C.; Di Tizio, A.; Mancinelli, R.; Grego, S.; Marinari, S. Soil biochemical indicators as a tool to assess the short-term impact of agricultural management on changes in organic $\mathrm{C}$ in a Mediterranean environment. Ecol. Indic. 2009, 9518-9527. [CrossRef]

25. Ghosh, A.; Bhattacharyya, R.; Meena, M.C.; Dwivedi, B.S.; Singh, G.; Agnihotri, R.; Sharma, C. Long-term fertilization effects on soil organic carbon sequestration in an Inceptisol. Soil Tillage Res. 2018, 177, 134-144. [CrossRef]

26. Nichols, K.A.; Wright, S.F. Comparison of glomalin and humic acid in eight native U.S. soils. Soil Sci. 2005, 170, 985-997. [CrossRef]

27. Janos, D.P.; Garamszegi, S.; Beltran, B. Glomalin extraction and measurement. Soil Biol. Biochem. 2008, 40, 728-739. [CrossRef]

28. Gillespie, A.W.; Farrell, R.E.; Walley, F.L.; Ross, A.R.S.; Leinweber, P.; Eckhardt, K.U.; Regier, T.Z.; Blyth, R.I.R. Glomalin-related soil protein contains non-mycorrhizal-related heat-stable proteins, lipids and humic materials. Soil Biol. Biochem. 2011, 43, 766-777. [CrossRef]

29. Singh, A.K.; Rai, A.; Pandey, V.; Singh, N. Contribution of glomalin to dissolved organic carbon under different land uses and seasonality in dry tropics. J. Environ. Manag. 2017, 192, 142-149. [CrossRef]

30. Preger, A.C.; Rillig, M.C.; Johns, A.R.; Du Preez, C.C.; Lobe, I.; Amelung, W. Losses of glomalin-related soil protein under prolonged arable cropping: A chronosequence study in sandy soils of the South African Highveld. Soil Biol. Biochem. 2007, 39, 445-453. [CrossRef]

31. Zhang, Z.; Wang, Q.; Wang, H.; Nie, S.; Liang, Z. Effects of soil salinity on the content, composition, and ion binding capacity of glomalin-related soil protein (GRSP). Sci. Total Environ. 2017, 581-582, 657-665. [CrossRef] 
32. Stehel, V.; Horák, J.; Vochozka, M. Prediction of institutional sector development and analysis of enterprises active in agriculture. Bus. Adm. Manag. 2019, 22, 103-117. [CrossRef]

33. Chemical and Agricultural Analysis_-Determining Soil pH; PN-ISO 10390; Polish Standards Committee: Warsaw, Poland, 1997.

34. Chemical and Agricultural Analysis-Determination of the Content of Available Phosphorus in Mineral Soils; PN-R-04023; Polish Standards Committee: Warsaw, Poland, 1996.

35. Chemical and Agricultural Analysis_Determination of the Content Available Potassium in Mineral Soils; PN-R-04022; Polish Standards Committee: Warsaw, Poland, 1996.

36. Chemical and Agricultural Analysis. Determination of the Content Available Magnesium; PN-R-04020; Polish Standards Committee: Warsaw, Poland, 1994.

37. Crock, J.G.; Severson, R. Four reference soil and rock samples for measuring element availability in the western energy regions. Geochem. Surv. Circ. 1980, 841, 1-16. [CrossRef]

38. Obrador, A.; Alvarez, J.M.; Lopez-Valdivia, L.M.; Gonzalez, D.; Novillo, J.; Rico, M.I. Relationships of soil properties with $\mathrm{Mn}$ and $\mathrm{Zn}$ distribution in acidic soils and their uptake by a barley crop. Geoderma 2007, 137, 432-443. [CrossRef]

39. Wright, S.F.; Upadhyaya, A. Extraction of an abundand and unusual protein from soil and comparison with hyphal protein of arbuscular mycorrhizal fungi. Soil Sci. 1996, 161, 575-586. [CrossRef]

40. Tabatabai, M.A.; Bremner, J.M. Use of p-nitrophenol phosphate for assay of soil phosphatase activity. Soil Biol. Biochem. 1969, 1, 301-307. [CrossRef]

41. Tratwal, A.; Roik, K.; Horoszkiewicz-Janka, J.; Wielkopolan, B.; Bandyk, A.; Jakubowska, M. Monitorowanie i Prognozowanie Chorób i Szkodników w Uprawie Zbóż i Kukurydzy; Centrum Doradztwa Rolniczego W Brwinowie: Poznań, Poland, 2015; p. 63. (In Polish)

42. Lamparski, R. Entomological and Biochemical Effects of the Application of Pro-Ecological Agrotechnical Treatments in Spring Barley; Wyd. UTP: Bydgoszcz, Poland, 2016.

43. United States Department of Agriculture (USDA). Keys to Soil Taxonomy, 10th ed.; United States Department of Agriculture, Natural Resources Conservation Service: Washington, DC, USA, 2006; 332p.

44. Pomorskie Towarzystwo Genealogiczne (PTG). Particle size distribution and textural classes of soil and mineral materials-Classification of Polish society of soil sciences 2008. Soil Sci. Ann. 2009, 60, 5-16.

45. Gonet, S.S. Ochrona Zasobów Materii Organicznej Gleb, [w:] Rola Materii Organicznej w Środowisku; Gonet, S.S., Markiewicz, M., Eds.; Polskie Towarzystwo Substancji Humusowych: Wrocław, Poland, 2007; pp. 7-29.

46. Pikuła, D. Environmental aspects of managing the organic matter in agriculture. Econ. Reg. Stud. 2015, 8, 98-112.

47. Keel, S.G.; Anken, T.; Buchi, L.; Chervet, A.; Fliessbach, A.; Flisch, R.; Huguenin-Elie, O.; Mader, P.; Mayer, J.; Sinaj, S.; et al. Loss of soil organic matter in Swiss long-term agricultural experiments over a wide range of management practices. Agric. Ecosyst. Environ. 2019, 286, 106654. [CrossRef]

48. Gałazka, A. The contents of total and easily extractable glomalin-related soil protein in different types of soil from the Polish crop of rye and wheat. Adv. Agric. Sci. 2016, 587, 3-11.

49. Wu, Q.S.; He, X.H.; Zou, Y.N.; He, K.P.; Sun, Y.H.; Cao, M.Q. Spatial distribution of glomalin-related soil protein and its relationships with root mycorrhization, soil aggregates, carbohydrates, activity of protease and $\beta$-glucosidase in the rhizosphere of Citrus unshiu. Soil Biol. Biochem. 2012, 45, 181-183. [CrossRef]

50. Lemanowicz, J.; Haddad, S.A.; Bartkowiak, A.; Lamparski, R.; Wojewódzki, P. The role of an urban park's tree stand in shaping the enzymatic activity, glomalin content and physicochemical properties of soil. Sci. Total Environ. 2020, 741, 140446. [CrossRef]

51. Hinsinger, P. Bioavailability of soil inorganic $\mathrm{P}$ in the rhizosphere as affected by root-induced chemical changes: A review. Plant Soil 2001, 237, 173-195. [CrossRef]

52. García-Ruiz, R.; Ochoa, V.; Hinojosa, M.B.; Carreira, J.A. Suitability of enzyme activities for the monitoring of soil quality improvement in organic agricultural systems. Soil Biol. Biochem. 2008, 40, 2137-2145. [CrossRef]

53. Guo, X.; Li, H.; Yu, H.; Li, W.; Ye, Y.; Biswa, A. Drivers of spatio-temporal changes in paddy soil pH in Jiangxi Province, China from 1980 to 2010. Sci. Rep. 2018, 8, 2702. [CrossRef] [PubMed]

54. Terelak, H.; Motowicka-Terelak, T.; Stuczyński, T.; Pietruch, C. Trace Elements (Cd, Cu, Ni, Pb, Zn) in Agricultural Soils of Arable Lands of Poland; IUNG: Warszawa, Poland, 2000. (In Polish)

55. Kabata-Pendias, A.; Pendias, P. Trace Elements in Soils and Plants, 3rd ed.; CRC Press: Boca Raton, FL, USA, 2001; ISBN 0-8493-1575-1. 
56. Koncewicz-Baran, M.; Gondek, K. Content of trace elements in agricultural soil. Infrastruct. Ecol. Rural Areas 2010, 14, 65-74. (In Polish)

57. Kwiatkowska-Malina, J. Functions of organic matter in polluted soils: The effect of organic amendments on phytoavailability of heavy metals. Appl. Soil Ecol. 2018, 123, 542-545. [CrossRef]

58. Jobbágy, E.G.; Jackson, R.B. The distribution of soil nutrients with depth: Global patterns and the imprint of plants. Biogeochemistry 2001, 53, 51-77. [CrossRef]

59. Ahmad, W.; Watts, M.J.; Imtiaz, M.; Ahmed, I.; Zia, M.H. Zinc deficiency in soil, crops and humans. Agrochimica 2012, 2, 86-97.

60. Rashad, M.; Elnaggar, E.; Assaad, F.F. Readily dispersible clay and its role in the mobility of transition metals $\mathrm{Cd}^{2+}, \mathrm{Cu}^{2+}$ and $\mathrm{Zn}^{2+}$ in an alkaline alluvial soil. Environ. Earth Sci. 2014, 71, 3855-3864. [CrossRef]

61. Sadeghzadeh, B. A review of zinc nutrition and plant breeding. J. Soil Sci. Plant Nutr. 2013, 13, $905-927$. [CrossRef]

62. Nannipieri, P.; Giagnoni, L.; Landi, L.; Renella, G. Role of phosphatase enzymes in soil. In Phosphorus in Action; Bünemann, E.K., Oberson, A., Frossard, E., Eds.; Springer: Berlin/Heidelberg, Germany, 2011; Volume 26, pp. 215-243. [CrossRef]

63. Abd El-Azeim, M.M.; Sherif, M.A.; Hussien, M.S.; Haddad, S.A. Temporal impacts of different fertilization systems on soil health under arid conditions of potato monocropping. J. Soil Sci. Plant Nutri. 2020, 20, 322-334. [CrossRef]

64. Feng, J.; Xu, X.; Wu, J.; Zhang, Q.; Zhang, D.; Li, Q.; Long, C.; Chen, Q.; Chen, J.; Cheng, X. Inhibited enzyme activities in soil macroaggregates contribute to enhanced soil carbon sequestration under afforestation in central China. Sci. Total Environ. 2018, 1, 653-661. [CrossRef]

65. Marinari, S.; Mancinelli, R.; Campiglia, E.; Grego, S. Chemical and biological indicators of soil quality in organic and conventional farming systems in Central Italy. Ecol. Indic. 2006, 6, 701-711. [CrossRef]

66. Lemanowicz, J. Activity of selected enzymes as markers of ecotoxicity in technogenic salinization soils. Environ. Sci. Pollut. Res. 2019, 26, 13014-13024. [CrossRef] [PubMed]

67. Lemanowicz, J. Mineral fertilisation as a factor determining selected sorption properties of soil against the activity of phosphatases. Plant Soil Environ. 2013, 59, 439-445. [CrossRef]

68. Piotrowska-Dlugosz, A.; Wilczewski, E. Soil phosphatase activity and phosphorus content as influenced by catch crops cultivated as green manure. Pol. J. Environ. Stud. 2014, 23, 157-165.

69. Kaniuczak, Z.; Beres, P. Occurrence and harmfulness of economically important cereals pests in ecological farms in Podkarpackie province in 2008-2010. J. Res. Appl. Agric. Eng. 2011, 56, 189-195.

70. Sempruch, C. Interactions between aphids and plants during early steps of the host selection. Kosmos 2012, $61,573-586$.

71. Lamparski, R.; Szczepanek, M. Entomophagous insects of the red fescue in the various condition of nitrogen fertilization. Prog. Plant Prot. 2008, 48, 357-361.

72. Beres, B.L.; Cárcamo, H.A.; Yang, R.C.; Spaner, D.M. Integrating spring wheat sowing density with variety selection to manage wheat stem sawfly. Agron. J. 2011, 103, 1755-1764. [CrossRef]

73. Ferraz, G.A.S.; Ferraz, P.F.P.; Martins, F.B.; Silva, F.M.; Damasceno, F.A.; Barbari, M. Principal components in the study of soil and plant properties in precision coffee farming. Agron. Res. 2019, 17, 418-429. [CrossRef]

74. Liu, C.W.; Lin, K.H.; Kuo, Y.M. Application of factor analysis in the assessment of groundwater quality in a blackfoot disease area in Taiwan. Sci. Total Environ. 2003, 313, 77-89. [CrossRef]

75. Asitok, A.; Ekpenyong, M.; Antai, S. Multivariate statistics of fertility parameter fluxes in cement-dust-polluted soils in Mfamosing, Nigeria: Impact on agriculture. J. Microbiol. Biotechnol. Food Sci. 2020, 9, 781. [CrossRef]

76. Ghaemi, M.; Astaraei, A.R.; Emami, H.; Mahalati, M.N.; Sanaeinejad, S.H. Determining soil indicators for soil sustainability assessment using principal component analysis of astan quds- east of mashhad- Iran. J. Soil Sci. Plant Nutr. 2014, 14, 987-1004. [CrossRef]

Publisher's Note: MDPI stays neutral with regard to jurisdictional claims in published maps and institutional affiliations. 